\title{
ISOTOPES' RADIOCARBON MEASUREMENTS VI
}

JAMES D. BUCKLEY, MILTON A. TRAUTMAN, and ERIC H. WILLIS

\section{ISOTOPES-A TELEDYNE COMPANY, Westwood, New Jersey}

\section{INTRODUCTION}

This list presents dates on a portion of the samples measured at ISOTOPES since publication of Isotopes $\mathrm{V}$, and for previously analyzed samples for which complete sample data are now available.

Samples were analyzed by gas proportional counting of carbon dioxide at $3 \mathrm{~atm}$ pressure in counters of 1 l. volume. Each sample was assayed twice, in different counters and on different days.

Procedures employed in sample preparation and age calculations have been described previously (Isotopes V).

\section{ACKNOWLEDGMENTS}

It is recognized that data obtained at this laboratory remain the sole property of our clients. We wish to thank those who have consented to have their data published here, and for their efforts in supplying informative comments.

We are greatly indebted to Mr. C. Tucek who, until April 1967, supervised the laboratory operations. We also wish to thank Miss B. Wallin, Mr. J. Bonicos, and Miss P. Kondratick for their painstaking assistance in the laboratory. Mrs. J. Barker supplied invaluable help in assembling the diverse mass of data associated with this listing.

$$
\text { I. GEOLOGIC SAMPLES }
$$

\section{A. Western United States}

\section{Fox series, Alaska}

Wood from Fox, $10 \mathrm{mi} \mathrm{N}$ of Fairbanks on Steese Highway $\left(64^{\circ} 57^{\prime}\right.$ N Lat, $147^{\circ} 37^{\prime}$ W Long), Alaska. Under ca. 45 ft frozen silt in U.S. Army Cold Regions Research and Engineering Laboratory's Alaska Permafrost Tunnel. Coll. and subm. 1965 by G. K. Swinzow, USA CRREL, Hanover, New Hampshire.

\section{I-1370. Fox, Alaska, $100 \mathrm{ft}$}

$11,000 \pm 280$

Light wood, $100 \mathrm{ft}$ depth, conifer root section.

\section{I-1369. Fox, Alaska, 59 ft}

$11,400 \pm 450$ 9450 в.C.

Dark wood, $59 \mathrm{ft}$ depth, (apparently willow).

General Comment (G.K.S.): perennially frozen Fairbanks silt has year round temperature of ca. $-2^{\circ} \mathrm{C}$. Formation contains partially decomposed floral and faunal remains; strong $\mathrm{H}_{2} \mathrm{~S}$ odor and traces of $\mathrm{CH}_{4}$ may indicate continuing decomposition in frozen state. Underlying this silt are productive auriferous gravels. 


\section{Barrow Drained Lake series, Alaska}

Peat from drained lake basin, Barrow $\left(71^{\circ} 19^{\prime} 00^{\prime \prime} \mathrm{N}\right.$ Lat, $156^{\circ} 34^{\prime}$ 45" W Long), Alaska. Coll. 1963 by J. Brown and P. V. Sellmann, U.S. Army Cold Regions Research and Engineering Lab., Hanover, New Hampshire; subm. 1964 by J. Brown.

\section{I-1544. Barrow Lake, upper}

$3200 \pm 230$

Buried lacustrine peat at $0.4 \mathrm{~m}$ depth consisting of frozen, wellpreserved, fibrous peat. Surface elev. $2.7 \mathrm{~m}$.

\section{I-1545. Barrow Lake, lower}

$5010 \pm 320$

Buried peat overlying inactive ice wedge at $1.2 \mathrm{~m}$ depth in same section as I-1544.

General Comment (J.B.): dates provide maximum ages for deposition of 2 peat layers in this 1 section, and which in turn provides maximum age bracket for formation and drainage of shallow arctic lake (Brown, 1965).

\section{$+3600$ \\ 31,400}

I-1604. Barrow Ridge, Alaska

29,450 B.c.

Finely divided organic matter from shaft of U.S. Coast and Geodetic Survey Seismic and Magnetic Installation located on vegetated inland beach ridge, Barrow ( $71^{\circ} 17^{\prime} 30^{\prime \prime} \mathrm{N}$ Lat, $156^{\circ} 35^{\prime} \mathrm{W}$ Long), Alaska. Sample from $5.6 \mathrm{~m}$ depth in sandy upper unit of Gubik formation. Coll. 1964 by J. Brown and P. V. Sellmann; subm. 1964 by J. Brown. Comment (J.B.): this sample, along with samples I-1384 and I-1394, provide dates for late Pleistocene events in N Alaska. Youngest date (I-1384, 25,300 \pm 2300 , Isotopes V) may represent marine transgression that took place prior to Wisconsin maximum. Date from the upper unit of Gubik (I1604, this sample) is 1st finite age for this deposit in N Alaska and is consistent with previous correlation of Wisconsin age. Date from lower unit (I-1394, >36,300 Isotopes $\mathrm{V}$ ) indicates pre-Wisconsin age for lower Barrow unit (Black, 1964; Brown, 1965; Sellmann et al., 1965).

\section{Barrow Spit series, Alaska}

Mosses from $1.5 \mathrm{~m}$ frozen peat core at sea level on gravel spit, Barrow $\left(71^{\circ} 21^{\prime} \mathrm{N}\right.$ Lat, $156^{\circ} 33^{\prime} \mathrm{W}$ Long), Alaska. Coll. 1965 by Jerry Brown, P. V. Sellmann, and Otto Engelberth; subm. 1965 by Jerry Brown.

I-1868. Upper $25 \mathrm{~cm}$

I-1949. Mid $25 \mathrm{~cm}$

I-1869. Lower $25 \mathrm{~cm}$
$2650 \pm 160$

690 B.c.

$2860 \pm 140$

910 в.C.

$4570 \pm 130$

2620 B.C. 
General Comment (J.B.): sequence provides evidence for filling and later burial of small coastal lake by transgressing sea, indicating sea level within several $\mathrm{m}$ of present level since 700 B.c. (Brown and Sellmann, 1966).

\section{Permafrost Tunnel series, Fairbanks, Alaska}

Samples from Permafrost Tunnel (64 $57^{\prime} \mathrm{N}$ Lat, $147^{\circ} 37^{\prime} \mathrm{W}$ Long), Fairbanks, Alaska. Coll. and subm. 1965 and 1966 by P. V. Sellmann.

\section{I-1841. Tunnel, 1 T $-350+6$}

$$
33,700 \begin{array}{r}
+2500 \\
-1900
\end{array}
$$

Twig from $40 \mathrm{ft}$ depth from exposure in wall of tunnel in Pleistocene valley silt section.

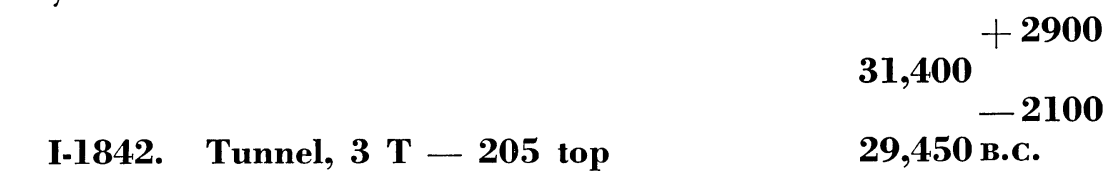

Organic residue (soluble and fibrous) extracted from ice-wedge. Comment (P.V.S.): sample dates oldest sequence of sediments exposed in valley section.

$$
32,300+2000
$$

I-1843. Tunnel, 2 T $-3+56 \quad 30,350$ B.c.

Organic residue (soluble and fibrous) extracted from ice-wedge.

$$
\begin{array}{ll} 
& \\
\text { I-2118. Tunnel-Vent, Shaft } 1966-\text { TS }(6) & \mathbf{5 0 2 0} \pm 135 \\
\text { B.c. }
\end{array}
$$
section.

Fine fibrous plant material from $6 \mathrm{ft}$ depth in Pleistocene valley silt

$$
\begin{array}{ll} 
& \\
\text { I-2119. Tunnel-Vent, Shaft } 1966-\text { TS (12) } & \mathbf{6 5 1 0} \pm 250
\end{array}
$$

Fine fibrous plant material from $12 \mathrm{ft}$ depth in Pleistocene valley silt section.

$$
\begin{array}{lr} 
& \\
\text { I-2120. Tunnel-Vent, Shaft } 1966-\text { TS (26) } & \mathbf{5 6 0} \pm \mathbf{\text { B.C. }}
\end{array}
$$

Fine fibrous plant material from $26 \mathrm{ft}$ depth in Pleistocene valley silt section.

$$
30,700+2100
$$

I-2121. Tunnel-Vent, Shaft 1966 - TS (34) 28,750 в.c.

Fine fibrous plant material from $34 \mathrm{ft}$ depth in Pleistocene valley silt section. 
General Comment (P.V.S.): series helps confirm Wisconsin age of sediments and dates period of large sized ice-wedge development (Sellmann, 1967).

\section{I-2593. Panamint Valley, California}

Scirpus seeds from Core II, 40 to $46 \mathrm{~cm}$ depth and Core III, 34 to $40 \mathrm{~cm}$ depth, Warm Sulphur Springs, Panamint Valley $\left(36^{\circ} 7^{\prime} \mathrm{N}\right.$ Lat, $117^{\circ} 13^{\prime} \mathrm{W}$ Long), California. Seeds were hand-picked from organic silt also containing molluscs and fossil pollen. Sorted sand lies below this horizon tentatively interpreted as shallow lake deposit. Coll. 1966 and subm. 1967 by P. J. Mehringer, Jr. Comment (P.J.M.): sample most probably predates 1870 because mesquite trees (Prosopis spp.), that are abundant in vicinity of spring, are mentioned in historic records and seeds subm. for dating are stratigraphically below occurrence of mesquite pollen.

\section{Niwot Ridge series, Boulder County, Colorado}

Soil samples from Niwot Ridge $\left(40^{\circ} 03^{\prime} 23^{\prime \prime} \mathrm{N}\right.$ Lat, $105^{\circ} 35^{\prime} 28^{\prime \prime} \mathrm{W}$ Long), 11,650 ft elev., Boulder County, Colorado. Coll. and subm. 1963 to 1965 by J. B. Benedict, Inst. Arctic and Alpine Research, Nederland, Colorado. Dating financed with grant from Soc. of Sigma Xi and RESA Research Fund.

\section{I-1792. 65-SBT-27.4 ft}

$2470 \pm 110$

Buried soil A horizon, $27.4 \mathrm{ft}$ in back of and ca. $4 \mathrm{ft}$ below surface of stone-banded solifluction terrace. Sample coll. at extreme upslope end of buried A horizon.

\section{I-1371. 63-SBT-20.7 ft}

$2020 \pm 110$ of stone-banked solifluction terrace.

\section{I-1698. 63-SBT-13 ft}

$$
1340 \pm 110
$$

Buried soil A horizon, $13.0 \mathrm{ft}$ in back of and ca. $4 \mathrm{ft}$ below surface of stone-banked solifluction terrace.

\section{I-1697. 63-SBT-5 ft}

$$
1250 \pm 120
$$

Buried soil A horizon, $5.0 \mathrm{ft}$ behind front, ca. $4 \mathrm{ft}$ below surface of stone-banked solifluction terrace.

\section{I-1510. 64-SBT-0 ft}

$355 \pm 115$

Modern soil A horizon, immediately in front of stone-banked solifluction terrace.

General Comment (J.B.B.): dates indicate that terrace began to form during Temple Lake time. Sample I-1510 was dated to make approx. cor- 
rection for age of $\mathrm{A}$ horizon at time of burial. Average rates of downslope movement during past 2500 yrs have been less than $4 \mathrm{~mm}$ per yr on this slope, except for brief period (1000 to 1200 B.P.) when they averaged ca. $23 \mathrm{~mm}$ per yr. Period of rapid movement is interpreted as an interval of increased soil moisture.

I-2214. Silver Peak Site, Nevada

$$
26,900+1200
$$

Clay core sample taken from $122 \mathrm{ft}$ depth in exploratory drill hole FX-6 (NE 1/4, sec. 17, T2 S, R39 E), Silver Peak Site, Nevada. Coll. and subm. 1966 by Foote Mineral Co., Exton, Pennsylvania.

\section{I-1505. Deschutes County, Oregon}

$6150 \pm 210$

4200 в.c.

Charcoal from Lava Cast Forest lava flow on Newberry Volcano $\left(43^{\circ}\right.$ $48^{\prime} \mathrm{N}$ Lat, $121^{\circ} 17^{\prime} \mathrm{W}$ Long), Deschutes County, Oregon. Charcoal found in void enclosed by lava. Coll. 1964 by N. V. Peterson and E. A. Groh; subm. 1964 by R. G. Bowen, Dept. of Geol. and Mineral Industries, Portland, Oregon.

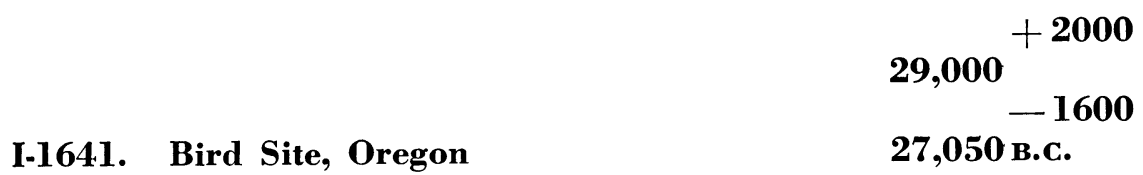

Snail shells from "Bird Site," $800 \mathrm{ft}$ E of Fossil Lake $\left(43^{\circ} 19^{\prime} \mathrm{N}\right.$ Lat, $120^{\circ} 29^{\prime}$ W Long), Lake County, Oregon. From 12-in. bed of sand and flat-pebble gravel immediately below 1- to 5-in. layer of white volcanic ash. Coll. 1964 and subm. 1965 by I. S. Allison, Dept. of Geol., Oregon State Univ., Corvallis, Oregon. Comment (I.S.A.): sample dates ash bed and assoc. vertebrate fossils.$$
+2500
$$$$
\mathbf{3 0 , 7 0 0}
$$ \\ I-1640. Lake County, Oregon \\ 28,750 B.c.}

Ostracods and oolites from seam 5 in. below biotite-bearing volcanic ash layer in Ana R. exposure, Summer Lake basin (42 $59^{\prime} \mathrm{N}$ Lat, $120^{\circ}$ 44' W Long), Lake County, Oregon. Coll. 1953 and subm. 1965 by I. S. Allison. Comment (I.S.A.): sample dates ash layer.

\section{I-959. Continental Shelf, Oregon}

$1845 \pm 180$

Organic carbon from gravity core coll. during R.V. Brown Bear Cruise 311 , Sta. 5, $78 \mathrm{fms}\left(46^{\circ} 01.8^{\prime} \mathrm{N}\right.$ Lat, $124^{\circ} 29.0^{\prime} \mathrm{W}$ Long), from continental shelf off coast of Oregon. Interval of green clayey silt 5 to $13 \mathrm{~cm}$ 
from top of $20 \mathrm{~cm}$ core. Coll. 1962 and subm. 1963 by D. A. McManus, Dept. of Oceanog., Univ. of Washington.

\section{I-798. Cascadia Basin, Northeast Pacific Ocean \\ $4800 \pm 300$} 312, Sta. 56 ( $46^{\circ} 145^{\prime} \mathrm{N}$ Lat, $127^{\circ} 00.0^{\prime} \mathrm{W}$ Long), Cascadia Basin, NE Pacific Ocean. From layer of grayish olive-green clayey silt 90 to $97 \mathrm{~cm}$ below top of $103 \mathrm{~cm}$ core. Coll. by Fritz Osell, Dept. of Oceanog., Univ. of Washington; subm. 1963 by D.A. McManus.

\section{I-800. Juan de Fuca Canyon, Washington}

$7990 \pm 600$

Organic carbon in piston core coll. during R. V. Brown Bear Cruise 291, Sta. 8 (47 39.0' N Lat, $125^{\circ} 38.0^{\prime}$ W Long), Juan de Fuca Canyon off coast of Washington. Interval between 269.5 and $276 \mathrm{~cm}$ in layer of olive-gray silty clay. Coll. and subm. 1963 by D. A. McManus.

\section{Continental Slope series, Washington}

Organic carbon coll. during R. V. Brown Bear Cruise 291, from continental slope off coast of Washington. Coll. and subm. 1963 by D. A. McManus.

\section{I-960. Continental Slope, No. 1}

Organic carbon in piston core from continental slope, Sta. $18\left(46^{\circ}\right.$ $41.0^{\prime} \mathrm{N}$ Lat, $125^{\circ} 12.0^{\prime} \mathrm{W}$ Long), off coast of Washington. Lowermost $8.5 \mathrm{~cm}$ in $514.5 \mathrm{~cm}$ gravity core.

\section{I-961. Continental Slope, No. 2}

$$
11,300 \pm 2000
$$

9350 B.c.

Organic carbon in piston core from continental slope, Sta. $18\left(46^{\circ}\right.$ $41.0^{\prime} \mathrm{N}$ Lat, $125^{\circ} 12.0^{\prime} \mathrm{W}$ Long), off coast of Washington. Interval from 366 to $373 \mathrm{~cm}$ below top of $514.5 \mathrm{~cm}$ gravity core in layer of predominantly greenish-black clay characteristic of upper $390 \mathrm{~cm}$ of core.

\section{I-962. Continental Slope, No. 3}

Organic carbon in piston core from continental slope, Sta. $18\left(46^{\circ}\right.$ 41.0' $\mathrm{N}$ Lat, $125^{\circ} 12.0^{\prime} \mathrm{W}$ Long), off coast of Washington. Transition layer 298 to $300 \mathrm{~cm}$ below top, between olive-gray' silty clay (above) and dark greenish-gray clay (below) in $514.5 \mathrm{~cm}$ core of predominantly clay with some sand layers.

\section{I-963. Continental Slope, No. 4}

$$
480 \pm 130
$$

Organic carbon in gravity core from continental slope, Sta. 19, 61 fms $\left(46^{\circ} 49.3^{\prime} \mathrm{N}\right.$ Lat, $124^{\circ} 36.3^{\prime} \mathrm{W}$ Long), off coast of Washington. In- 
terval between 9 and $16.5 \mathrm{~cm}$ from top in $16.5 \mathrm{~cm}$ length core. Composed of olive-gray sandy silt.

\section{I-964. Continental Slope, No. 5}

$1120 \pm 220$

Organic carbon in gravity core from continental slope, Sta. $62\left(46^{\circ}\right.$ 21.8' N Lat, $124^{\circ} 17.8^{\prime} \mathrm{W}$ Long), off coast of Washington. Interval between 20 and $28 \mathrm{~cm}$ from top of core in layer of olive-gray silt (depth 10 to $29 \mathrm{~cm}$ ). Core stopped in shell rich layer of sandy silt, total core length $48.5 \mathrm{~cm}$.

\section{I.965. Continental Slope, No. 6}

$2475 \pm 175$

525 B.C.

Organic carbon in gravity core from continental slope, Sta. $62\left(46^{\circ}\right.$ $21.8^{\prime} \mathrm{N}$ Lat, $124^{\circ} 17.8^{\prime} \mathrm{W}$ Long), off coast of Washington. Interval between 39 and $45 \mathrm{~cm}$ from top in layer of olive-gray sandy silt.

\section{I-1430. Cobb Seamount D-19, Washington}

$6710 \pm 330$

4760 в.c.

Mytilus shells coll. in pipe dredge recovery during R. V. Brown Bear Cruise 139, from 55 fms on " 45 fms" terrace, SW side Cobb Seamount $\left(46^{\circ} 46.2^{\prime}\right.$ N Lat, $130^{\circ} 49.0^{\prime}$ W Long), N Pacific Ocean, Washington. Sample also included subrounded basalt cobbles and pebbles, and Pecten fragments (Budinger and Enbysk, 1960). Coll. 1956 by T. F. Budinger, Dept. of Oceanog., Univ. of Washington, Seattle, Washington; subm. 1964 by B. J. Enbysk. Comment (B.J.E.): date may be too young as overgrowth of probably much more recent encrusting organisms might not have been adequately removed. Other materials will be submitted from this terrace.

\section{Deep Sea Core series, Washington}

Marine mud from deep sea core $326-36$, (46 $29.0^{\prime} \mathrm{N}$ Lat, $124^{\circ} 42^{\prime}$ 24" W Long), off coast of Washington. Coll. and subm. 1963 by C. F. Royse, Dept. of Geol., Univ. of North Dakota, Grand Forks, North Dakota.

I-1258. Upper Core, 3261

$1680 \pm 120$

Depth $360 \mathrm{fms}, 0$ to $19 \mathrm{~cm}$ in core.

\section{I-1259. Middle Core, 326-2}

$4860 \pm 200$

2910 B.c.

Depth $360 \mathrm{fms} .132$ to $150 \mathrm{~cm}$ in core.

\section{I-1260. Lower Core, 326-3}

$7755 \pm 300$ 5805 в.c.

Depth $360 \mathrm{fms}, 250$ to $265 \mathrm{~cm}$ in core.

General Comment (G.F.R.): dating organic portion of 3 intervals of single core indicates average depositional rate to be ca. $41 \mathrm{~cm}$ per 1000 
yr off Washington coast. Average depositional rate is considered representative of pelagic sedimentation on upper continental slope off Washington state. Rates for upper and lower portions of core indicate sedimentation has been nearly constant during last $6000 \mathrm{yr}$. A 4-cm-thick ash layer at $240-\mathrm{cm}$ level would date ca. $5700 \mathrm{yr}$ в.P. by applying average sedimentation rate of $50 \mathrm{mg} \mathrm{cm}^{-2} \mathrm{yr}^{-1}$. Source of ash may be from eruption of Mt. Mazama (Royse, 1964).

\section{I-1881. Orcas Island, Washington}

$12,600 \pm 190$ 10,650 в.c.

Shells from Orcas Island (48 $37^{\prime} \mathrm{N}$ Lat, $123^{\circ} 01^{\prime} \mathrm{W}$ Long), Washington. In pebbly clay more than $100 \mathrm{ft}$ above sea level. Coll. and subm. 1964 by D. J. Easterbrook, W. Washington State College, Bellingham, Washington. Comment (D.J.E.): dates late Pleistocene glaciomarine drift on Orcas Island.

\section{I-1880. Whidbey Island, Washington}

$$
\begin{aligned}
& 34,900+3000 \\
& 32,950 \text { в.с. }
\end{aligned}
$$

Peat from Whidbey Island (48 $18^{\prime} \mathrm{N}$ Lat, $122^{\circ} 30^{\prime} \mathrm{W}$ Long), Washington. Interbedded with gravel, $5 \mathrm{ft}$ above sea level. Coll. and subm. 1965 by D. J. Easterbrook. Comment (D.J.E.): peat and gravel sequence overlain by Vashon till. Age of 26,850 $\pm 1,700$ was obtained higher in sequence at this locality.

I-2159. Astoria Canyon, 6508-C-14, Washington

Calcite and dolomite in piston core coll. by R. V. Yaquina in 358 $\mathrm{m}$ of water, 30 nautical $\mathrm{mi} \mathrm{W}$ of mouth of Columbia $\mathrm{R}$. near $\mathrm{S}$ edge of Astoria Canyon ( $46^{\circ} 03.2^{\prime} \mathrm{N}$ Lat, $124^{\circ} 45.7^{\prime} \mathrm{W}$ Long), Washington. From depth 156 to $166 \mathrm{~cm}$ in $230 \mathrm{~cm}$ core. Coll. 1965 and subm. 1966 by K. L. Russell, Dept. of Oceanog., Oregon State Univ., Corvallis, Oregon.

\section{I-2307. Astoria Canyon, 6502-3-7, Washington}

$5620 \pm 145$

3670 B.c.

Marine sediment containing magnesium-rich calcite coll. in $815 \mathrm{fms}$ of water by R. V. Yaquina from bottom of Astoria Canyon (46 05.2' N Lat, $125^{\circ} 00.7^{\prime} \mathrm{W}$ Long), Washington. In uniform sequence of green pelagic clays at depth $2.04 \mathrm{~m}$ in core, carbonate layer only $2 \mathrm{~cm}$ thick (Ph.D. Thesis by Paul Carlson, Dept. of Oceanog., Oregon State Univ.). Coll. 1965 and subm. 1966 by K. L. Russell.

\section{B. Central United States}

\section{I-1719. Warren County, Illinois}

$16,000 \pm 340$

Snail shells from grayish layer within "Iowan age" loess in $13 \mathrm{ft}$ section of Peorian loess (Ruhe et al., 1957; Leighton and Willman, 1950) at depth 7 to $8 \mathrm{ft}$, Warren County $\left(40^{\circ} 54^{\prime} \mathrm{N}\right.$ Lat, $90^{\circ} 45^{\prime} \mathrm{W}$ Long), 
Illinois. Coll. 1965 by J. D. Alexander and H. L. Wascher; subm. 1965 by H. L. Wascher, Univ. of Illinois, Dept. of Agronomy, Urbana, Illinois.

\section{I-1720. Henderson County, Illinois}

$13,700 \pm 260$

Snail shells from 4 to $5 \mathrm{ft}$ depth in loess section more than $25 \mathrm{ft}$ thick (Ruhe et al., 1957; Leighton and Willman, 1950) in Henderson County (41 ${ }^{\circ} 1^{\prime} \mathrm{N}$ Lat, $90^{\circ} 52^{\prime} \mathrm{W}$ Long), Illinois. Coll. 1965 by J. D. Alexander and H. L. Wascher; subm. 1965 by H. L. Wascher.

\section{I-1963. Peoria County, Illinois, No. 1}

$24,100 \pm 600$

Organic material from upper 20 in. of peat bed at depth 135 to 155 in., Peoria County $\left(40^{\circ} 35^{\prime} \mathrm{N}\right.$ Lat, $89^{\circ} 48^{\prime} \mathrm{W}$ Long), Illinois. Sample composed of fragments of leaves and stems of herbs, shrubs, and grasses or sedges stratified with gray silt thought to be earliest part of Peorian loess or latest part of Farmdale loess deposition time. Coll. 1965 by J. D. Alexander and H. L. Wascher, subm. 1965 by H. L. Wascher. Comment (H.L.W.): age yields reasonable date for ending of Farmdale and beginning of Peorian loess deposition (Ruhe et al., 1957; Leighton and Willman, 1950).

\section{I-1964. Peoria County, Illinois, No. 2}

$26,100 \pm 900$

Organic material from 30 -in. peat bed in Peoria County $\left(40^{\circ} 35^{\prime} \mathrm{N}\right.$ Lat, $89^{\circ} 48^{\prime} \mathrm{W}$ Long), Illinois. Sample from depth 155 to 185 in., immediately beneath I-1963. Coll. 1965 by J. D. Alexander and H. L. Wascher; subm. 1965 by H. L. Wascher. Comment (H.L.W.): age agrees with other datings of Farmdale time.

\section{I-1962. Stephenson County, Illinois}

$>39,900$

Decomposed organic material with charcoal and woody fragments from middle of 9-in. horizon of paleo-humic gley at depth 223 to $232 \mathrm{in}$., $6 \mathrm{mi} \mathrm{W}$ of Freeport, Stephenson County, E of center sec. 1, T26 N, R6 E (42 $17^{\prime} \mathrm{N}$ Lat, $89^{\circ} 45^{\prime} \mathrm{W}$ Long), Illinois. Horizon developed on accretion-gley buried by Peorian loess 0 to 209 in., and stratified silts and organic bands from 202 to 223 in., underlain by gleyed clay loam. Coll. and subm. 1965 by L. R. Follmer, Univ. of Illinois, Dept. of Agronomy, Urbana, Illinois. Comment (L.R.F.): attempts to date paleosol which developed on drift beyond limits of Shelbyville drift in NW Illinois (Kempton, 1963; Ruhe et al., 1957).

\section{Colo Bog series, Iowa}

Peaty muck from SW 1/4 NW 1/4 sec. 11, T83 N, R21 W, Colo Bog (42 ${ }^{\circ} 1^{\prime} \mathrm{N}$ Lat, $93^{\circ} 15^{\prime} \mathrm{W}$ Long), Story County, Iowa. Coll. 1962 by $\mathrm{P}$. H. Walker and W. L. Jackson; subm. 1963 by R. V. Ruhe, Iowa State Univ., Ames Iowa. 
I-1013. Colo Bog, No. 1

From grass pollen zone, 34 to 36 in. depth in core.

I-1014. Colo Bog, No. 2

$8320 \pm 275$

6370 B.c.

From hardwood forest pollen zone, 11 to $11.25 \mathrm{ft}$ depth in core.

I-1015. Colo Bog, No. 3

$13,775 \pm 300$

From conifer pollen zone, 15.5 to $15.75 \mathrm{ft}$ depth in core.

\section{Jewell Bog series, Iowa}

Peaty muck from NW 1/4 sec. 19, T86 N, R24 W, Jewell Bog $\left(42^{\circ}\right.$ 14' N Lat, 93 41' W Long), Hamilton County, Iowa. Coll. 1962 by P. H. Walker and W. L. Jackson; subm. 1963 by R. V. Ruhe.

I-1016. Jewell Bog, No. 1

$2365 \pm 500$

From grass pollen zone, 24 to 26 in. depth in core.

I-1017. Jewell Bog, No. 2

$10,230 \pm 400$

8280 B.C.

From hardwood-conifer pollen zone, 17.5 to $17.75 \mathrm{ft}$ depth in core.

I-1018. Jewell Bog, No. 3

$10,670 \pm 400$

8720 B.c.

From conifer-hardwood pollen zone, 23.3 to $23.5 \mathrm{ft}$ depth in core.

I-1019. Jewell Bog, No. 4

$$
11,640 \pm 400
$$

9690 B.c.

From conifer pollen zone, 28 to $28.5 \mathrm{ft}$ depth in core.

Jewell Bog, Core 2 series, Iowa

Peaty muck from NW 1/4 sec. 19, T86 N, R24 W, Jewell Bog $\left(42^{\circ}\right.$ $14^{\prime} \mathrm{N}$ Lat, $93^{\circ} 41^{\prime} \mathrm{W}$ Long), Hamilton County, Iowa. Coll. 1964 by P. H. Walker and W. L. Jackson; subm. 1965 by R. V. Ruhe.

\section{I-1417. Jewell Bog, A}

$9570 \pm 180$

From middle part of lower peaty muck, conifer-hardwood pollen zone, 14.7 to $15 \mathrm{ft}$ depth in core.

I-1418. Jewell Bog, B

$10,640 \pm 270$

8690 B.C.

From base of lower peaty muck, conifer pollen zone, 19.67 to $20 \mathrm{ft}$ depth in core.

\section{I-1023. Bentley, Iowa}

$21,360 \pm 850$

19,410 B.c.

Spruce wood from organic zone at base of Wisconsin loess in cut along Rock Island R.R., NW 1/4 sec. 21, T76 N, R41 W, Bentley $\left(41^{\circ}\right.$ 
22' N Lat, 95 35' W Long), Pottawattamie County, Iowa. Depth 43 to 44 ft. Coll. 1961 and subm. 1963 by R. V. Ruhe.

\section{Madrid series, Polk County, Iowa}

Spruce wood from loess interbedded between tills in $\mathrm{E}$ road cut of State Highway 60 on S valley slope of Des Moines R., NW 1/4 sec. 30, T81 N, R25 W, Madrid (41 ${ }^{\circ} 47^{\prime}$ N Lat, 93 49' W Long), Polk County, Iowa. Coll. 1961 by R. V. Ruhe and W. H. Scholtes; subm. 1963 by R. V. Ruhe.

\section{I-1024. Madrid, No. 1}

$16,100 \pm 500$

From 30 to $31 \mathrm{ft}$ depth.

\section{I-1025. Madrid, No. 2}

14,150 B.c.

From $52 \mathrm{ft}$ depth.

\section{Palermo area, Grundy County series, Iowa}

Organic carbon from silts between tills, NW $1 / 4$ sec. 29 , T87 N, R17 W, Palermo area ( $42^{\circ} 20^{\prime} \mathrm{N}$ Lat, $92^{\circ} 51^{\prime} \mathrm{W}$ Long), Grundy County, Iowa. Coll. 1964 by T. E. Fenton and R. C. Shuman; subm. 1964 by R. V. Ruhe.

\section{I-1265. Palermo, No. 1}

From 42 to $42.5 \mathrm{ft}$ depth in core.

I-1266. Palermo, No. 2

From A horizon of paleosol on lower till, 44 to $45 \mathrm{ft}$ depth in core.

\section{I-1267. Hayward Paha, Tama County, Iowa}

$$
25,000 \pm 2500
$$

Organic carbon from base of Wisconsin loess above YarmouthSangamon paleosol in center, sec. 36, T86 N, R13 W, Hayward Paha (42 $13^{\prime} \mathrm{N}$ Lat, $92^{\circ} 18^{\prime} \mathrm{W}$ Long), Tama County, Iowa. From 35 to 35.5 ft depth in core. Coll. 1963 by T. E. Fenton and R. C. Shuman; subm. 1964 by R. V. Ruhe.

\section{I-1268. Stratford, Hamilton County, Iowa}

$$
13,900 \pm 400
$$

$$
\text { 11,950 в.c. }
$$

Spruce wood from base of Cary till, NW 1/4 sec. 6, T86 N, R26 W, Stratford (42 $17^{\prime} \mathrm{N}$ Lat, $93^{\circ} 56^{\prime} \mathrm{W}$ Long), Hamilton County, Iowa. From 64 to $65 \mathrm{ft}$ depth. Coll. 1963 by P. H. Walker, W. L. Jackson, and R. V. Ruhe; subm. 1964 by R. V. Ruhe.

\section{I-1269. Salt Creek, Tama County, Iowa}

$$
29,000 \pm 3500
$$

Organic carbon from base of Wisconsin loess above YarmouthSangamon paleosol, NE 1/4 NW 1/4 sec. 7, T84 N, R14 W, Salt Creek $\left(42^{\circ} 6^{\prime} \mathrm{N}\right.$ Lat, $92^{\circ} 34^{\prime} \mathrm{W}$ Long), Tama County, Iowa. From 43 to $44 \mathrm{ft}$ 
depth. Coll. 1963 by G. F. Hall and T. E. Fenton; subm. 1964 by R. V. Ruhe.

I-1270. Boone, Boone County, Iowa

$16,100 \pm 1000$

Spruce wood from loess interbedded between tills in $\mathrm{N}$ cut along new U.S. Highway 30 on W valley slope of Des Moines R. in center, sec. 2, T83 N, R27 W, Boone ( $42^{\circ} 2^{\prime}$ N Lat, $93^{\circ} 57^{\prime}$ W Long), Boone County, Iowa. From 25 to $25.5 \mathrm{ft}$ depth. Coll. and subm. 1964 by R. V. Ruhe.

\section{I-1402. Nevada, Story County, Iowa}

$14,200 \pm 500$

Spruce wood from loess interbedded between tills in S cut at Nevada interchange along new U.S. Highway 30 at NC sec. 18, T83 N, R22 W, Nevada ( $41^{\circ} 59^{\prime} \mathrm{N}$ Lat, $93^{\circ} 27^{\prime} \mathrm{W}$ Long), Story County, Iowa. From 14 ft depth. Coll. and subm. 1964 by R. V. Ruhe.

\section{1,950 в.c.}

Peat from base of Wisconsin loess, foundation excavation beneath Roberts Theater on Grinnell College campus, sec. 9, T80 N, R16 W,

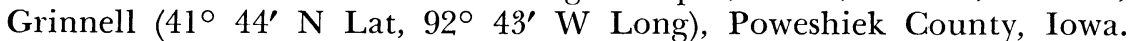
From 12 to $12.5 \mathrm{ft}$ depth. Coll. 1960 by B. F. Graham; subm. 1964 by R. V. Ruhe.

\section{Palermo, Core 2 series, Iowa}

Organic carbon from sec. 29, T87 N, R17 W, Palermo area $\left(42^{\circ} 19^{\prime}\right.$ N Lat, $92^{\circ} 52^{\prime} \mathrm{W}$ Long), Grundy County, Iowa. Coll. 1964 by R. V. Ruhe and G. F. Hall; subm. 1965 by R. V. Ruhe.

\section{I-1404. Palermo area, $A$}

From base of Wisconsin loess at SW corner, 17.5 to $18 \mathrm{ft}$ depth in core.

I-1405. Palermo area, B in core.

From silts interbedded between tills at SW corner, 30 to $31 \mathrm{ft}$ depth

\section{I-1406. Kinross, Keokuk County, Iowa}

$24,600 \pm 1100$ $\mathbf{2 2 , 6 5 0}$ в.c.

Organic carbon from base of Wisconsin loess, SE $1 / 4$ SW $1 / 4$ sec. 27, T77 N, R10 W, Kinross ( $41^{\circ} 26^{\prime} \mathrm{N}$ Lat, $91^{\circ} 58^{\prime} \mathrm{W}$ Long), Keokuk County, Iowa. From 10.5 to $11 \mathrm{ft}$. depth in core. Coll. 1964 by R. I. Dideriksen and J. A. Kovar; subm. 1965 by R. V. Ruhe.

I-1408. Harvard, Wayne County, Iowa

$19,200 \pm 900$

Organic carbon from base of Wisconsin loess, NW $1 / 4$ sec. 15, T68 N, R21 W, Harvard (404' N Lat, $93^{\circ} 16^{\prime}$ W Long), Wayne County, 
Iowa. From 7.6 to $8.3 \mathrm{ft}$ depth in core. Coll. 1964 by W. P. Dietz and J.

D. Highland; subm. 1965 by R. V. Ruhe.

I-1409. Hayward Paha, Iowa

Organic carbon from base of Wisconsin loess above lower part of Yarmouth-Sangamon paleosol beveled by Iowan erosion surface in center, sec. 36, T86 N, R13 W, Hayward Paha $\left(42^{\circ} 13^{\prime} \mathrm{N}\right.$ Lat, $92^{\circ} 18^{\prime} \mathrm{W}$ Long), Tama County, Iowa. From 11 to $11.5 \mathrm{ft}$ depth in core. Coll. 1964 by T. E. Fenton and W. P. Dietz; subm. 1965 by R. V. Ruhe.

\section{I-1411. Greenfield, Adair County, Iowa}

$18,700 \pm 700$ 16,750 в.c.

Organic carbon from base of Wisconsin loess, WC sec. 17, T76 N, R31 W, Greenfield ( $41^{\circ} 22^{\prime}$ N Lat, $94^{\circ} 27^{\prime}$ W Long), Adair County, Iowa. From 14.3 to $15 \mathrm{ft}$ depth in core. Coll. 1964 by R. V. Ruhe and W. P. Dietz; subm. 1965 by R. V. Ruhe.

\section{McCulloch Bog series, Hancock County, Iowa}

Peaty muck from SE 1/4 sec. 32, T94 N, R24 W, McCulloch Bog $\left(42^{\circ} 55^{\prime} \mathrm{N}\right.$ Lat, $93^{\circ} 43^{\prime} \mathrm{W}$ Long), Hancock County, Iowa. Coll. 1964 by P. H. Walker and W. L. Jackson; subm. 1965 by R. V. Ruhe.

\section{I-1412. McCulloch Bog, No. 1}

From grass pollen zone, base of upper peat, 36 to 38 in. depth in core.

\section{I-1413. McCulloch Bog, No. 2}

From hardwood forest pollen zone, upper part of lower peaty muck, 11.25 to $11.5 \mathrm{ft}$ depth in core.

\section{I-1414. MeCulloch Bog, No. 3}

$14,500 \pm 340$

12,550 B.c.

From conifer pollen zone, base of lower peaty muck, 19.3 to $19.5 \mathrm{ft}$ depth in core.

\section{Woden Bog series, Hancock County, Iowa}

Peaty muck and organic carbon at NE corner, sec. 13, T97 N, R26 W, Woden Bog ( $43^{\circ} 13^{\prime}$ N Lat, $94^{\circ} 53^{\prime}$ W Long), Hancock County, Iowa. Coll. 1964 and 1965 by P. H. Walker, L. H. Durkee, and W. L. Jackson; subm. 1965 by R. V. Ruhe.

\section{I-1415. Woden Bog, No. 1}

Upper part of lower peaty muck, hardwood forest pollen zone, 21.25 to $21.5 \mathrm{ft}$ depth in core. 
I-1416. Woden Bog, No. 2

$11,570 \pm 330$

9620 B.C.

Organic carbon from lower silts, conifer pollen zone, 31.5 to $32.5 \mathrm{ft}$ depth in core.

I-1852. Woden Bog, No. 3

$2830 \pm 115$

880 B.C.

Organic carbon below base of upper peat, grass pollen zone, 25 to 28 in. depth in core.

I-1853. Woden Bog, No. 4

$5390 \pm 125$

3440 B.C. in core.

Organic carbon from upper silts, grass pollen zone, 8 to $8.5 \mathrm{ft}$ depth

\section{I-1854. Woden Bog, No. 5}

$7770 \pm 140$

Upper part of lower peaty muck, hardwood forest pollen zone, 24.25 to $24.5 \mathrm{ft}$ depth in core.

I-1855. Woden Bog, No. 6

$9300 \pm 130$

Organic carbon from lower silts, hardwood forest pollen zone, 27.5 to $27.75 \mathrm{ft}$ depth in core.

\section{I-1419A. Humeston, Wayne County, Iowa}

$16,500 \pm 500$

14,550 в.c.

Organic carbon from base of Wisconsin loess, SE 1/4 sec. 21, T69 N, R23 W, Humeston (40 $45^{\prime} \mathrm{N}$ Lat, $93^{\circ} 31^{\prime} \mathrm{W}$ Long), Wayne County, Iowa. From Yarmouth-Sangamon paleosol, 8.5 to $9.25 \mathrm{ft}$ depth in core. Coll. 1964 by W. P. Dietz, J. D. Highland, T. E. Fenton, and R. V. Ruhe; subm. 1965 by R. V. Ruhe. Comment (R.V.R.): humic acid fraction removed with $2 \mathrm{Na} \mathrm{OH}$ treatments.

\section{I-1419B. Humeston, Wayne County, Iowa}

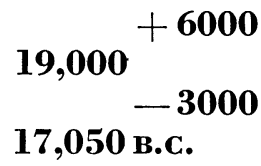

Organic carbon from base of Wisconsin loess, SE 1/4 sec. 21, T69 N, R23 W, Humeston ( $40^{\circ} 45^{\prime} \mathrm{N}$ Lat, $93^{\circ} 31^{\prime} \mathrm{W}$ Long), Wayne County, Iowa. From Yarmouth-Sangamon paleosol, 8.5 to $9.25 \mathrm{ft}$ depth in core. Coll. 1964 by W. P. Dietz, J. D. Highland, T. E. Fenton, and R. V. Ruhe; subm. 1965 by R. V. Ruhe. Comment (R.V.R.): humic-acid fraction date.

\section{I-1420. Bentley, Pottawattamie County, Iowa 21,950 B.c.}

$23,900 \pm 1100$

Organic carbon from buried soil A horizon, NW $1 / 4$ sec. 21, T76 $\mathrm{N}, \mathrm{R} 41 \mathrm{~W}$, Bentley (41 $22^{\prime} \mathrm{N}$ Lat, $95^{\circ} 35^{\prime} \mathrm{W}$ Long), Pottawattamie County, Iowa. From base of Wisconsin loess that contained spruce wood (I-1023, this date list), depth 43 to $44 \mathrm{ft}$. Coll. 1964 and subm. 1965 by 
R. V. Ruhe. Comment (R.V.R.): reasonable agreement between soil organic carbon and wood date indicates validity of buried soil organic carbon as dating medium.

\section{I-1421. Wolf Creek, Tama County, Iowa \\ 130 B.C.}

$2080 \pm 115$

American elm $\log$ from $9 \mathrm{ft}$ depth on $\mathrm{N}$ stream bank, NE $1 / 4 \mathrm{sec}$. 24, T86 N, R13 W, Wolf Creek (42 $14^{\prime} \mathrm{N}$ Lat, $92^{\circ} 18^{\prime} \mathrm{W}$ Long), Tama County, Iowa. Overlying alluvium noncalcareous. Coll. 1964 by R. V. Ruhe, W. P. Dietz, and G. F. Hall; subm. 1965 by R. V. Ruhe.

\section{I-1978. Barney Lake, Michigan}

$7280 \pm 160$

Sedge and Sphagnum peat from sediment core under $4 \mathrm{ft}$ of water at SE end of Barney Lake, Beaver Island, Charlevoix County $\left(45^{\circ} 43^{\prime} \mathrm{N}\right.$ Lat, $85^{\circ} 34^{\prime} \mathrm{W}$ Long), Michigan. From ca. $30 \mathrm{~cm}$ above basal sand of core and beneath marly gyttja and sand. Coll. and subm. 1965 by S. B. Bushouse and R. O. Kapp, Alma College, Biology Dept., Alma, Michigan. Comment (S.B.B.): date indicates peat was formed during Chippewa low water stage in Lake Michigan basin (Bushouse and Kapp, as mss.).

\section{I-1718. Winona County, Minnesota}

$205 \pm 115$

Wood from stump rooted in recent alluvial silt, now exposed in bed of Whitewater R., NE 1/4, NW 1/4, sec. 11, Twp. 108 N, Range 10 W, Winona County (44 $12^{\prime} \mathrm{N}$ Lat, $91^{\circ} 59^{\prime} \mathrm{W}$ Long), Minnesota. Coll. 1964 and subm. 1965 by S. C. Happ, U.S. Dept. of Agriculture, Oxford, Mississippi. Comment (S.C.H.): date indicates somewhat more aggradation of stream bed during past 100 to $300 \mathrm{yr}$ than had been previously recognized.$$
32,300+2000
$$ \\ I-1851. Gilman Canyon, Nebraska

Soil-like material from road cut to Gilman Canyon floor, $90 \mathrm{ft}$ below upland surface, lower $1 \mathrm{ft} 10$ in. of Gilman Canyon Formation (5 ft $9 \mathrm{in}$. thick) SW, SW, SE, sec. 7, TION, R26 W(40 $51^{\prime} \mathrm{N}$ Lat $100^{\circ} 19^{\prime} \mathrm{W}$ Long), Lincoln County, Nebraska. Coll. 1965 by J. A. Elder, V. H. Dreeszen, and E. C. Reed, Nebraska Geol. Surv.; subm. 1965 by E. C. Reed. Comment (E.C.R.): date confirms Reed and Dreeszen's (1965) classification of Gilman Canyon Formation as Early Wisconsinan. Previously regarded as A-horizon of Sangamon Soil.

\section{Eastern United States}

\section{Quaise Marsh series, Massachusetts}

Peat immediately above hard substratum at $\mathrm{S}$ end of Quaise Marsh $\left(41^{\circ} 72^{\prime} 22^{\prime \prime} \mathrm{N}\right.$ Lat, $70^{\circ} 02^{\prime} 30^{\prime \prime} \mathrm{W}$ Long), Massachusetts. Salt marsh 
vegetated with dwarf form of Spartina alterniflora. Coll. and subm. 1964 by J. M. Zeigler and A. C. Redfield, Woods Hole Oceanog. Institution, Woods Hole, Massachusetts.

\section{I-1441. Quaise March, 4.3 to $4.8 \mathrm{ft}$ depth}

$$
\begin{array}{r}
1305 \\
\text { A.D. } 645
\end{array}
$$

I-1442. Quaise Marsh, 6.3 to $6.8 \mathrm{ft}$ depth

A.D. 255

$1695 \pm 110$

General Comment (A.C.R.): dates help determine recent rate of rise in relative sea level and agree with similar measurements at Barnstable, Massachusetts (Redfield and Rubin, 1962).

\section{Nauset Marsh series, Massachusetts}

Peat immediately above hard substratum in small salt marsh adjoining Nauset Marsh and $\mathrm{W}$ of Cape Cod Natl. Seashore headquarters $\left(41^{\circ} 50^{\prime} 42^{\prime \prime} \mathrm{N}\right.$ Lat, $69^{\circ} 57^{\prime} 0^{\prime \prime} \mathrm{W}$ Long), Eastham, Massachusetts. Surface of marsh covered with Spartina potens. Coll. and subm. 1965 by G. Bartlett and A. C. Redfield.

\section{I-1967. Nauset Marsh, 10.2 to $10.7 \mathrm{ft}$ depth}

$$
\begin{gathered}
2300 \pm 105 \\
350 \text { B.c. } \\
3460 \pm 100 \\
1510 \text { B.C. }
\end{gathered}
$$

I-1968. Nauset Marsh, 17.2 to $17.7 \mathrm{ft}$ depth

General Comment (A.C.R.): dates help determine recent rate of rise in relative sea level and are consistent with similar measurements at Barnstable, Massachusetts (Redfield and Rubin, 1962).

\section{Milton Salt Marsh series, Massachusetts}

Peat from salt marsh on SE side of Neponset R., N of Milton Hill (42 $16^{\prime} \mathrm{N}$ Lat, $70^{\circ} 03.5^{\prime} \mathrm{W}$ Long), Massachusetts. Coll. 1966 by A. C. Redfield and A. E. Waller; subm. 1966 by A. C. Redfield.

\section{I-2215. Milton Salt Marsh, 1.1 to $1.5 \mathrm{ft}$ depth A.D. 640 \\ $1360 \pm 105$ \\ I-2216. Milton Salt Marsh, 2.1 to $2.5 \mathrm{ft}$ depth A.D. 590 \\ I-2217. Milton Salt Marsh, 3.1 to $3.5 \mathrm{ft}$ depth A.D. 90 \\ $1860 \pm 100$}

$1310 \pm 95$

General Comment (A.C.R.): samples from this location at greater depth have been dated but have not been published.

\section{Riverhead Salt Marsh series, New York}

Peat from salt marsh on W side Reeves Bay, Riverhead $\left(40^{\circ} 54.8^{\prime} \mathrm{N}\right.$ Lat, $72^{\circ} 37.4^{\prime} \mathrm{W}$ Long), New York. Below $8.5 \mathrm{ft}$ depth, peat is of fresh water origin (Johnson, 1925). Coll. 1963 by A. C. Redfield, R. Fairbridge, and W. Newman; subm. 1966 by A. C. Redfield. 
I-2076. Spartina peat, depth 7.4 to $7.7 \mathrm{ft}$

$$
\begin{aligned}
& 3900 \pm 105 \\
& 1950 \text { B.C. }
\end{aligned}
$$

\section{$\mathbf{8 0 7 0} \pm 130$ \\ I-2077. Fresh water peat, depth 11.2 to $11.7 \mathrm{ft} \quad 6120$ B.c.}

General Comment (A.C.R.): samples from this location analyzed by Lamont have yielded results as follows: L-863A, depth 3.5 to $4.0 \mathrm{ft}, 930$ \pm 150 ; L-863D, depth 14.7 to $15.2 \mathrm{ft}, 10,950 \pm 300$ (unpubl.).

\section{I-838. Malloy Farm site, New York}

$$
\begin{aligned}
& 12,100 \pm 400 \\
& 10,150 \text { в.c. }
\end{aligned}
$$

Wood (spruce) from Malloy Farm site, Ewings Road, N of Lockport $\left(43^{\circ} 14^{\prime} 20^{\prime \prime} \mathrm{N}\right.$ Lat, $78^{\circ} 42^{\prime} 30^{\prime \prime} \mathrm{W}$ Long), New York. From layer of organic material containing fresh water mosses and shells ca. 6 in. thick beneath 10 to $12 \mathrm{ft}$ coarse sand and gravel, elev. $360 \mathrm{ft}$. Recent find is $71 / 2$ lb. 113/4 in. mammoth tooth. Coll. and subm. 1963 by R. L. McCarthy, Board of Education, Lockport, New York. Comment (R.L.C.): dates $\mathbf{N}$ edge of old Lake Iroquois.

\section{Walden Creek Marsh series, Southport, N. Carolina}

Peat (attributed to Juncus roemerianus) immediately above clay sub-

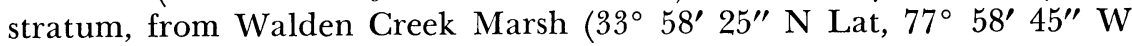
Long), Southport, N. Carolina. Sample length $0.5 \mathrm{ft}$, depth measured from surface of (Disticlis spicata vegetated) marsh. Coll. and subm. 1964 by A. C. Redfield and A. W. Cooper.

\section{I-1576. Depth 4.4 to $4.9 \mathrm{ft}$}

$2310 \pm 130$

\section{I-1577. Depth 6.4 to $6.9 \mathrm{ft}$}

360 в.c.

\section{1-1577. Depth 6.4 to $6.9 \mathrm{ft}$}

I-1578. Depth 9.25 to $9.75 \mathrm{ft}$

$3100 \pm 120$

1150 B.C.

\section{I-1579. Depth 10.4 to $10.9 \mathrm{ft}$}

$3920 \pm 130$ 1970 B.C.

$3720 \pm 140$ 1770 B.C.

General Comment (A.C.R.): purpose of series was to determine recent rate of rise in relative sea level. Data accords with similar measurements at Newburyport, Massachusetts (McIntire and Morgan, 1963).

\section{Singletary Lake series, N. Carolina}

Silt and mud using a large diameter piston corer, from Singletary Lake (34 $36^{\prime} \mathrm{N}$ Lat, $78^{\circ} 27^{\prime} \mathrm{W}$ Long), Bladen County, N. Carolina. Coll. 1962 by D. R. Whitehead and D. H. Hamilton, III, Williams College, Williamstown, Massachusetts; subm. 1965 by D. R. Whitehead. 
I-1752. Singletary Lake, $1.04 \mathrm{~m}$

$5750 \pm 135$ (1) organic horizon. Comment (D.R.W.): date supports pollen data indicating post-glacial correlation.

I-1751. Singletary Lake, $1.41 \mathrm{~m}$

$11,000 \pm 200$ 9050 B.C.

Gray lake silt, 1.41 to $1.49 \mathrm{~m}$ depth in core, from top of upper silt in profile. Comment (D.R.W.): date supports pollen data indicating lateglacial correlation.

\section{I-1750. Singletary Lake, $1.685 \mathrm{~m}$}

$16,200 \pm 290$

Gray lake silt, 1.685 to $1.735 \mathrm{~m}$ depth in core, from middle of upper silt horizon. Comment (D.R.W.): date supports pollen data indicating full-glacial correlation.

$$
\begin{gathered}
35,800+3200 \\
\text { 33,850 в.с. }
\end{gathered}
$$

I-1748. Singletary Lake, $2.02 \mathrm{~m}$

Gray lake silt, 2.02 to $2.07 \mathrm{~m}$ depth in core, from base of upper silt zone. Comment (D.R.W.): date and pollen data indicate correlation with Port Talbot interstadial.

I-1749. Singletary Lake, $2.30 \mathrm{~m}$

Fibrous gel-mud, 2.30 to $2.34 \mathrm{~m}$ depth in core, from middle organic horizon. Comment (D.R.W.): date and pollen data suggest correlation with Port Talbot interstadial. Pollen spectra show time of climatic amelioration and low-water phase of lake (Frey, 1951; Whitehead, 1963; 1964).

\section{Canada}

I-2244. Peace River tusk, British Columbia

$7670 \pm 170$

5720 B.c.

N. American elephant tusk from $50 \mathrm{ft}$ depth in terminal moraine at E edge of Rocky Mt. Foothills on Great Plains, Portage Pass, Peace R. District ( $56^{\circ} \mathrm{N}$ Lat, $122^{\circ} 10^{\prime} \mathrm{W}$ Long), British Columbia, Canada. Coll. 1966 by L. T. Jory; subm. 1966 by D. D. Campbell, Dolmage, Campbell and Assoc., Vancouver, British Columbia, Canada. Comment (D.D.C.): date indicates some elephants survived longer than previously believed in ice fringes of Canadian Rocky Mts. Most recent dated elephant remains in U.S.A. are ca. 2000 yr older than this specimen.

\section{I-2245. Duncan River, British Columbia}

$355 \pm 90$

Driftwood from evergreen tree at $15 \mathrm{ft}$ depth in river-deposited sand and gravel away from present river bed, Duncan R. Valley, N end of 
Kootenay Lake $\left(50^{\circ} 20^{\prime} \mathrm{N}\right.$ Lat, $116^{\circ} 55^{\prime} \mathrm{W}$ Long), British Columbia, Canada. Coll. 1966 by P. Ottesen; subm. 1966 by D. D. Campbell. Comment (D.D.C.): date indicates in 355 yr Duncan R. deposited 15-ft sand and gravel.

I-2259. Peace River, British Columbia

Charcoal (crumbly) remnant of burnt tree from $S$ terrace of Peace R. where it issues onto Great Plains from Rocky Mts., Hudson Hope $\left(56^{\circ} \mathrm{N}\right.$ Lat, $122^{\circ} \mathrm{W}$ Long), British Columbia, Canada. From 6-in. discontinuous layer of charcoal $15 \mathrm{ft}$ below upper surface of $100-\mathrm{ft}$ thick buried sequence of sand and gravel. Coll. and subm. 1966 by D. D. Campbell. Comment (D.D.C.): date represents interval when proglacial lake on Canadian Plains had either completely or very appreciably receded, allowing rejuvenated Peace R. to flow eastward across lake beds.

\section{I-1911. Port Hope, Ph 1, Ontario}

$345 \pm 175$

Wood with organic soil from 25 to $35 \mathrm{~cm}$ thick horizon at $2 \mathrm{~m}$ depth in stoney glacial till from Port Hope $\left(43^{\circ} 57^{\prime} \mathrm{N}\right.$ Lat, $78^{\circ} 20^{\prime} \mathrm{W}$ Long), Ontario, Canada. Coll. and subm. 1965 by J. C. Ritchie, Trent Univ., Peterborough, Ontario, Canada. Comment (J.C.R.): plant macrofossil and pollen analyses are being conducted on this material (Coleman, 1936; Gravenor, 1957).

\section{I-2106. Russell Pond, Ru-1, Manitoba}

$10,250 \pm 140$

8300 B.C.

Gyttja (limnic sediment) from Russell $\left(50^{\circ} 48^{\prime} \mathrm{N}\right.$ Lat, $100^{\circ} 78^{\prime} \mathrm{W}$ Long), Manitoba, Canada. At 386 to $391 \mathrm{~cm}$ level of lake sediments, immediately below transition to heavy clay sediment. Coll. and subm. 1966 by J. C. Ritchie. Comment (J.C.R.): sample from late-glacial (Picea-Shepherdia canadensis-Artemisia forest community) to hypsithermal (grassland spectra) when lake was intermittently dry.

\section{Manitoba series, Canada}

Limnic sediment from nameless lake near Belmont, Manitoba $\left(49^{\circ}\right.$ 26' N Lat, 99 $26^{\prime} \mathrm{W}$ Long), Canada. Coll. and subm. 1967 by J. C. Ritchie.

\section{I-3156. Belmont-BT 22}

From $195 \mathrm{~cm}$ depth in lake sediments, at transition from grass-herb dominated assemblages (pollen) to oak-birch assemblage.

\section{I-3157. Belmont-BT 115}

$9430 \pm 160$

From $610 \mathrm{~cm}$ depth in lake sediments, at transition from spruce dominated pollen zone to grassland zone, probably marking beginning of hypsithermal.

General Comment (J.C.R.): lake is ca. $20 \mathrm{~km}$ from Glenboro site, for 
which Isotopes C-14 determinations have provided a chronology. Pollen diagrams from these lakes are consistent.

\section{E. Europe}

\section{I-1543. Benbecula, Scotland}

$5700 \pm 170$

Coniferous wood from Barve Beach, SW coast of Island of Benbecula $\left(57^{\circ} 26^{\prime} \mathrm{N}\right.$ Lat, $7^{\circ} 21^{\prime} \mathrm{W}$ Long), Scotland. Sample found in sequence of organic material interstratified with sand, $1 \mathrm{ft} 10$ in. below ordnance datum. Coll. and subm. 1964 by W. Ritchie. Comment (W.R.): pollen techniques show most of organic material to be derived from fresh water marsh vegetation. Date and sample stratigraphic position give index of amount and rate of sealevel change.

\section{I-1667. Northwich, Cheshire}

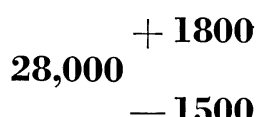

Mollusc, (Nucella lapillus, Linné) from gravel pit near Northwich, Cheshire (53 $13^{\prime} 30^{\prime \prime} \mathrm{N}$ Lat, $2^{\circ} 35^{\prime} 20^{\prime \prime} \mathrm{W}$ Long), England. Shells were taken from base of till and sand complex, Upper Boulder Clay of Cheshire. Coll. 1965 by P. Worsley; subm. 1965 by C. S. Boulton, Keele Univ., Staffordshire, England. Comment (C.S.B.): till-sand complex is part of drift sheet which represents last advance of ice into Cheshire-Shropshire basin and is related to Late Weichselian Max. of $\mathrm{N}$ Europe (Boulton and Worsley, 1965).

\section{I-1687. Druidston Irish Sea Till}

Mollusca fragments from St. Bridges Bay, Pembrokeshire $\left(51^{\circ} 48^{\prime}\right.$ $20^{\prime \prime} \mathrm{N}$ Lat, $5^{\circ} 5^{\prime} 40^{\prime \prime} \mathrm{W}$ Long), S Wales. Sample coll. from coastal exposure of Irish Sea Till capped by outwash deposits. Coll. and subm. 1965 by B. S. John, Univ. of Oxford, Oxford, England. Comment (B.S.J.): stratigraphic evidence indicates Druidston Irish Sea Till is same age as outwash deposits. Outwash from Pembrokeshire was dated at younger than 38,000 yr B.P. (John, 1965). Mollusc species of both till and outwash datings were the same, and considered to represent Main Würm Age (Synge, 1964).

\section{N Norwegian Sea series, Norway}

Organic carbon core samples taken while aboard USS Edisto from $\mathrm{N}$ Norwegian Sea $\left(70^{\circ} 00^{\prime} \mathrm{N}\right.$ Lat, $0^{\circ} 00^{\prime} \mathrm{W}$ Long), Norway. Coll. 1963 and subm. 1965 by J. S. Creager, Dept. of Oceanog., Univ. of Washington.

\section{I-1694. No. 1}

$19,200 \pm 3100$

Yellowish-brown sediment between 4 to $22 \mathrm{~cm}$ from top of $118.5 \mathrm{~cm}$ piston core. Comment (J.S.C.): stratigraphy indicates environment of 
sedimentation in this particular area is similar to those existing in entire Norwegian Sea immediately following close of Pleistocene Epoch.

\section{I-1695. No. 2}

$17,900 \pm 900$

Medium dark-gray sediment between 27 to $55 \mathrm{~cm}$ from top of 118.5 $\mathrm{cm}$ piston core. Comment (J.S.C.): date indicates sediment may have been deposited by drifting glacial ice during late Pleistocene time.

\section{I-1696. No. 3}

$22,200 \pm 1800$

Medium dark-gray sediment between 93 to $121 \mathrm{~cm}$ from top of 118.5 $\mathrm{cm}$ piston core. Comment (J.S.C.): date indicates sediment may have been deposited by drifting glacial ice during late Pleistocene time.

\section{Maanselänsuo series, Finland}

Biogenic material from wall of ditch in Maanselänsuo fen $\left(65^{\circ} 37^{\prime} \mathrm{N}\right.$ Lat, 29 38' E Long), Kuusamo, Finland. Coll. Oct. 1964 and subm. Apr. 1965 by Yrjö Vasari, Univ. of Oulu, Oulu, Finland.

\section{I-1699. Maanselänsuo, No. 1}

$9100 \pm 220$

Alternating layers of fine sand and mosses (Drepanocladus exannulatus s. str.), from depth 175 to $185 \mathrm{~cm}$ in transition zone from overlying peat to fine sand (Vasari, 1965a). Comment (Y.V.): sample represents "Upper Paleoholocene" phase in vegetational history of Kuusamo district (supposedly synchronous with Younger Dryas) and taken to date that phase.

\section{I-1700. Maanselänsuo, No. 2}

$9150 \pm 220$

7200 B.c.

Lowermost layer of Bryales-Carex peat, at depth 165 to $170 \mathrm{~cm}$ (Vasari, 1965a). Comment (Y.V.): sample represents beginning of "Lower Eoholocene" phase in local vegetational history. This, together with results of other samples (I-1699, this series; I-775 and I-777, Isotopes V), indicate change from park-tundra phase ("Upper Paleoholocene") into birch forest phase ("Lower Eoholocene"), occurred at different times in different places. This change occurred mainly during pre-Boreal, but at times as late as Boreal period.

\section{I-1701. Maanselänsuo, No. 3}

$6500 \pm 180$

Carex peat from depth 110 to $115 \mathrm{~cm}$ (Vasari, 1965a). Comment (Y.V.): sample dates beginning of "Upper Mesoholocene" phase in local vegetational history. Age confirms concept that "Upper Mesoholocene" corresponds to Zone VII in zoning system of Jessen. 
I-1702. Maanselänsuo, No. 4

$1900 \pm 130$

Sphagnum-Carex peat with wood from depth 55 to $60 \mathrm{~cm}$ (Vasari, 1965a). Comment (Y.V.): sample was expected to date boundary between "Lower Neoholocene" and "Upper Neoholocene," supposedly corresponding to Sub-Boreal and Sub-Atlantic transition). Age obtained is too recent. No correlatives for these periods can be distinguished in pollen diagrams from Kuusamo district (Vasari, 1965b; I-1703, this date list).

\section{I-1703. Mäkelä, Finland}

$3550 \pm 150$

Highly humified peat from Mäkelä $\left(66^{\circ} 01^{\prime} \mathrm{N}\right.$ Lat, $29^{\circ} 15^{\prime} \mathrm{E}$ Long), Kuusamo, Finland. From bottommost layer of peat (ca. $20 \mathrm{~cm}$ thick) covering steep hill slope. Coll. 1964 and subm. 1965 by Yrjö Vasari. Comment (Y.V.): sample taken in connection with studies on age of peat formation on hill-slopes. On basis of pollen analysis, sample was expected to represent "Upper Neoholocene" phase; age however, indicates peat originated from sub-Boreal period (Vasari, 1965b; I-1702, this date list).

\section{I-1758. Maanselkä, Finland}

$1095 \pm 115$

"Humic acid" extracted from B horizon of iron podzol profile in spruce forest at Maanselkä (65 $54^{\prime} \mathrm{N}$ Lat, $29^{\circ} 01^{\prime} \mathrm{E}$ Long), Kuusamo, Finland. Coll. 1964 and subm. 1965 by Yrjö Vasari.

\section{I-1759. Kurvinen, Finland}

$\mathbf{5 3 0} \pm \mathbf{1 3 0}$

"Humic acid" extracted from B horizon of iron podzol profile in spruce forest at Kurvinen ( $65^{\circ} 36^{\prime} \mathrm{N}$ Lat, $29^{\circ} 38^{\prime} \mathrm{E}$ Long), Kuusamo, Finland. Coll. 1964 and subm. 1965 by Yrjö Vasari.

\section{I-1760. Kuusamo, Finland}

"Humic acid" extracted from B horizon of iron podzol profile in dry Pinus silvestris-lichen forest on sandy ground at center of Kuusamo commune (66 $01^{\circ} \mathrm{N}$ Lat, 29 $29^{\circ} \mathrm{E}$ Long), Finland. Coll. 1964 and subm. 1965 by Yrjö Vasari. Comment (Y.V.): ages obtained from "humic acid" (samples I-1758, I-1759, and I-1760, this date list) indicate renewal of humus material in podzols is relatively rapid.

\section{Southwest Finland series}

Peat samples taken with piston core from raised bogs in Finland. Coll. and subm. 1965 by Toive Aartolahti, Dept. of Geog., Univ. of Helsinki, Finland (Aartolahti, 1966).

\section{I-1804. Vähäsuo Bog, Finland} Vähäsuo bog ( $60^{\circ} 45^{\prime} 38^{\prime \prime}$ N Lat, $23^{\circ} 49^{\prime} 5^{\prime \prime}$ E Long), Tammela, Finland. 


\section{I-1805. Vähäsuo Bog, Finland}

Peat (Sphagnum) from raised bog, 2.15 to $2.20 \mathrm{~m}$ depth, Vähäsuo bog $\left(60^{\circ} 45^{\prime} 38^{\prime \prime} \mathrm{N}\right.$ Lat, $23^{\circ} 49^{\prime} 5^{\prime \prime}$ E Long), Tammela, Finland. Comment (T.A.): vigorous spread of Picea began in area at this level.

I-1806. Linturahka Bog, Finland

$3470 \pm 110$

1520 B.c.

Peat (Sphagnum-Carex) from raised bog, 2.95 to $3.00 \mathrm{~m}$ depth, Linturahka bog $\left(60^{\circ} 42^{\prime} 39^{\prime \prime} \mathrm{N}\right.$ Lat, $22^{\circ} 59^{\prime} 41^{\prime \prime}$ E Long), Mellilä, Finland.

\section{I-1807. Linturahka Bog, Finland}

$3400 \pm 110$

Peat (Sphagnum-Carex) from raised bog, 2.90 to $2.95 \mathrm{~m}$ depth, Linturahka bog $\left(60^{\circ} 42^{\prime} 39^{\prime \prime} \mathrm{N}\right.$ Lat, $22^{\circ} 59^{\prime} 41^{\prime \prime}$ E Long), Mellilä, Finland. Comment (T.A.): vigorous spread of Picea began in area at this level.

\section{I-1808. Isosuo Bog, Finland}

$3390 \pm 110$

Woody peat (Carex) from raised bog, 2.48 to $2.53 \mathrm{~m}$ depth, Isosuo bog $\left(60^{\circ} 30^{\prime} 32^{\prime \prime} \mathrm{N}\right.$ at, $22^{\circ} 15^{\prime} 19^{\prime \prime}$ E Long), Turku, Finland. Comment (T.A.): vigorous spread of Picea began just above this level.

\section{I-1810. Haukjärvenneva Bog, Finland}

$3700 \pm 115$

1750 B.c.

Peat (Carex) from raised bog, 2.68 to $2.73 \mathrm{~m}$ depth, Haukjärvenneva bog $\left(61^{\circ} 51^{\prime} \mathrm{N}\right.$ Lat, $\left.21^{\circ} 33^{\prime} \mathrm{E} \mathrm{Long}\right)$, Siikainen, Finland.

\section{I-1811. Haukjärvenneva Bog, Finland}

$3300 \pm 120$

Woody peat (Carex) from raised bog, 2.63 to $2.68 \mathrm{~m}$ depth, Haukjärvenneva bog ( $61^{\circ} 51^{\prime} \mathrm{N}$ Lat, $21^{\circ} 33^{\prime} \mathrm{E}$ Long), Siikainen, Finland. Comment (T.A.): vigorous spread of Picea in area at this level.

\section{I-1874. Mustaneva Bog, Finland}

$4060 \pm 120$

Peat (Carex-Sphagnum) from raised bog, 3.90 to $3.95 \mathrm{~m}$ depth, Mustaneva bog $\left(60^{\circ} 41^{\prime} 33^{\prime \prime} \mathrm{N}\right.$ Lat, $24^{\circ} 59^{\prime} 27^{\prime \prime}$ E Long), Hausjärvi, Finland. Comment (T.A.): vigorous spread of Picea began in area at this level.

\section{I-1875. Mustaneva Bog, Finland}

$4090 \pm 120$

Peat (Carex-Sphagnum) from raised bog, 3.95 to $4.00 \mathrm{~m}$ depth, Mustaneva bog (60 $41^{\prime} 33^{\prime \prime}$ N Lat, $24^{\circ} 59^{\prime} 27^{\prime \prime}$ E Long), Hausjärvi, Finland.

\section{Haapasuo Bog series, Finland}

Peat and gyttja taken with piston drill from Haapasuo bog, Askola (60 $34^{\circ} \mathrm{N}$ Lat, $25^{\circ} 36^{\prime}$ E Long), Finland. Coll. and subm. 1965 by $\mathrm{R}$. Tynni, Geol. Survey, Otaniemi, Finland. 
I-1884. Haapasuo 1

$9230 \pm 150$

7280 B.C.

Peat (Bryales-Equisetum). Comment (R.T.): according to pollen analysis, peat is of pre-Boreal age.

\section{I-1887. Haapasuo 2}

$8600 \pm 140$

(Equisetum) gyttja and peat. Comment (R.T.): date in accord with pollen analysis of Boreal age.

\section{I-1886. Haapasuo 3}

$7120 \pm 140$

5170 B.C.

(Sphagnum) peat. Comment (R.T.): date corresponds with rise of Alnus-pollen curve at transition Boreal to early Atlantic.

\section{I-1885. Martinsuo Bog, Finland}

$3300 \pm 110$

1350 B.c.

Peat (Deciduos) taken with piston drill from Martinsuo bog $\left(60^{\circ}\right.$ $34^{\prime} \mathrm{N}$ Lat, $25^{\circ} 39^{\prime}$ E Long), Askola, Finland. Coll. and subm. 1962 by R. Tynni. Comment (R.T.): dated horizon corresponds to rise of Piceapollen curve at transition sub-Boreal to sub-Atlantic.

\section{Råbacka series, Finland}

Peat and detritus gyttja from $36 \mathrm{~km} \mathrm{~N}$ of Helsinki $\left(60^{\circ} 29^{\prime \prime} 47^{\prime \prime} \mathrm{N}\right.$ Lat, $24^{\circ} 57^{\prime}$ 27' E Long), Finland (Mölder, Valovirta, and Virkkala, Bull. 178). Coll. and subm. 1965 by K. Virkkala, Geol. Survey, Otaniemi, Finland.

\section{I-1923. Råbacka 1}

$3510 \pm 110$

(Carex-Sphagnum) peat from depth 0.30 to $0.35 \mathrm{~m}$ in bog. Comment (K.V.): Subboreal time (Zone VIII), beginning of common occurrence of spruce.

\section{I-1924. Råbacka 2}

$7960 \pm 150$

(Sphagnum-Carex) peat from depth 1.15 to $1.25 \mathrm{~m}$ in bog. Comment (K.V.): zone boundary V/VI, beginning of common occurrence of alder.

\section{I-1925. Råbacka 3}

$8550 \pm 160$

\section{0 в.C.}

(Carex) peat from depth 1.7 to $1.8 \mathrm{~m}$ in bog. Comment (K.V.): Zone V, Boreal Pinus maximum.

\section{I-1926. Råbacka 4}

$8880 \pm 140$

(Carex) peat from depth 1.85 to $1.95 \mathrm{~m}$ in bog. Comment (K.V.): Zone Boundary $\mathrm{IV} / \mathrm{V}$. 
I-1927. Råbacka 5

Detritus gyttja from 2.1 to $2.2 \mathrm{~m}$ depth in bog. Comment (K.V.): Zone IV, Preboreal Betula-maximum.

\section{F. Africa}

\section{I-929. Wadi Halfa area, Sudan}

$12,720 \pm 350$

10,770 в.C.

Pelecypod shell (Corbicula artini) from $200 \mathrm{~m} \mathrm{E}$ of Nile on Khor Kidingkong in Akasha district $100 \mathrm{~km} \mathrm{SW}$ of Wadi Halfa $\left(20^{\circ} 15^{\prime} \mathrm{N}\right.$ Lat, $31^{\circ} 14^{\prime} \mathrm{E}$ Long), Sudan. Site is $15 \mathrm{~m}$ above Nile flood level, and $195 \mathrm{~m}$ above MSL in upper soft pale-gray Sebilian silt, $20 \mathrm{~m}$ below top. No associated fossils. Coll. 1961 and subm. 1962 by C. W. Sutton, Millburn Mus. Comment (C.W.S.): bivalves mostly with valves together, minimizing possibility of reworking or transportation by currents. Shells occupy rich horizon in former backwater of river in thick sequence of silts otherwise barren. Since overlying $20 \mathrm{~m}$ of silt is uninterrupted, date reflects youngest high oscillation of Nile when siltation built valley to $35 \mathrm{~m}$ above present flood level. Time may correspond to warm (Alleröd) interstadial of Europe and N. America.

\section{G. Australia}

\section{I-1135. Curracurrang Cove, Australia}

$$
2150 \pm 180
$$

Wood charcoal from Curracurrang Cove, Royal Natl. Park $\left(34^{\circ} 8^{\prime}\right.$ $50^{\prime \prime} \mathrm{S} \mathrm{Lat}, 151^{\circ} 6^{\prime} 25^{\prime \prime}$ E Long), New South Wales, Australia. Sample found in compact occupation layer, rich in humic material, in coastal rock shelter. Coll. 1962 and subm. 1963 by J. V. S. Megaw, Univ. of Sydney, New South Wales, Australia. Comment (J.V.S.M.): Curracurrang represents a cultural development as postulated by McCarthy (1961). Sample associated with bandi points and geometric microliths. Date agrees with others obtained in E Australia with geometric microliths (McBryde, 1961; Mulvaney, 1962) but is lst to be associated with bandi points.

\section{H. Mexico}

\section{West Coast of Mexico series}

Clayey silt from Middle American Trench coll. with 2.5 in I.D. gravity core. Coll. 1963 by D. A. Ross; subm. 1964 by R. D. McIver, Jersey Production Research Co., Tulsa, Okahoma.

\section{I-1529. 338 B}

$6030 \pm 320$

From continental flank of M.A.T. $\left(19^{\circ} 00^{\prime} 48^{\prime \prime} \mathrm{N}\right.$ at, $105^{\circ} 21^{\prime} \mathrm{W}$ Long), 0 to $12 \mathrm{~cm}$ in core; water depth $3,861 \mathrm{~m}$. 


\section{I-1530. 338 B}

$9890 \pm 380$

From continental flank of M.A.T. $\left(19^{\circ} 00^{\prime} 48^{\prime \prime} \mathrm{N}\right.$ Lat, $105^{\circ} 21^{\prime} \mathrm{W}$ Long), 27 to $41 \mathrm{~cm}$ in core; water depth $3,861 \mathrm{~m}$.

I-1531. 338 B

$11,500 \pm 350$

9550 B.C.

From continental flank of M.A.T. $\left(19^{\circ} 00^{\prime} 48^{\prime \prime} \mathrm{N}\right.$ Lat, $105^{\circ} 21^{\prime} \mathrm{W}$ Long), 54 to $65 \mathrm{~cm}$ in core; water depth $3,861 \mathrm{~m}$.

I-1532. 340, 0-12 $\mathrm{cm}$

$1270 \pm 200$

From bottom of M.A.T. (18 $55^{\prime} 30^{\prime \prime} \mathrm{N}$ Lat, $105^{\circ} 23^{\prime} 48^{\prime \prime} \mathrm{W}$ Long), 0 to $12 \mathrm{~cm}$ in core; water depth 4,787 to $4,795 \mathrm{~m}$.

I-1533. 340, 51-61 cm

$2170 \pm 190$

220 B.c.

From bottom of M.A.T. (18 $55^{\prime} 30^{\prime \prime}$ N Lat, $105^{\circ} 23^{\prime} 48^{\prime \prime}$ W Long), 51 to $61 \mathrm{~cm}$ in core; water depth 4,787 to $4,795 \mathrm{~m}$.

I-1534. 340, 95-105 cm

$2440 \pm 210$

From bottom of $M$ 95 to $105 \mathrm{~cm}$ in core; water depth 4,787 to $4,795 \mathrm{~m}$.

I-1535. 368, 0-11 cm

$2080 \pm 125$

From seaward flank of M.A.T. 130 B.C. Long), 0 to $11 \mathrm{~cm}$ in core; water depth 4,202 $\mathrm{m}$.

I-1536. 368, $27-39 \mathrm{~cm}$

$4530 \pm 200$

2580 B.c.

From seaward flank of M.A.T. $\left(19^{\circ} 22^{\prime} 54^{\prime \prime} \mathrm{N}\right.$ Lat, $106^{\circ} 05^{\prime} 06^{\prime \prime} \mathrm{W}$ Long), 27 to $39 \mathrm{~cm}$ in core; water depth $4,202 \mathrm{~m}$.

\section{I-1537. 368, 76-90 $\mathrm{cm}$}

$9490 \pm 380$

From seaward flank of M.A.T. $\left(19^{\circ} 22^{\prime} 54^{\prime \prime}\right.$ ⒌ 740 B.c. Long), 76 to $90 \mathrm{~cm}$ in core; water depth $4,202 \mathrm{~m}$.

I-1538. PG 414, 0-11 cm

$1510 \pm 120$

A.D. 440

From bottom of M.A.T. (21 $06^{\prime} 48^{\prime \prime} \mathrm{N}$ Lat, $106^{\circ} 26^{\prime} 06^{\prime \prime} \mathrm{W}$ Long), 0 to $11 \mathrm{~cm}$ in core; water depth $4,154 \mathrm{~m}$.

I-1539. PG 414, 23-35 cm

$2100 \pm 215$

23 to $35 \mathrm{~cm}$ in core; water depth $4,154 \mathrm{~m}$. 
I-1540. PG 414, 76-88 cm

From bottom of M.A.T. (21 $21^{\circ} 46^{\prime \prime}$ N Lat, $106^{\circ} 26^{\prime} 06^{\prime \prime} \mathrm{W}$ Long), 76 to $88 \mathrm{~cm}$ in core; water depth $4,154 \mathrm{~m}$.

General Comment: samples were submitted as strontium carbonate.

\section{Bermuda}

\section{Bermuda Marsh series, Bermuda}

Peat, organic silt, and clay from Shelly Bay and Long Bay, Bermuda. Purpose of series was to determine rate of rise of relative sea level. Coll. and subm. 1965 by A. C. Redfield, Woods Hole Oceanog. Inst., Massachusetts.

\section{I-1683. Shelly Bay, 5.2 ft}

$1850 \pm 110$

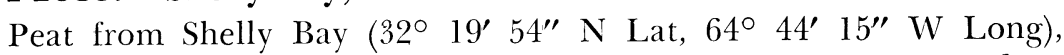
swamp separated from sea by shelly sand beach. Depth estimated re MSL at Ferry Reach, Bermuda. From depth -5.4 to $-5.7 \mathrm{ft}$ from $0.2 \mathrm{ft}$ above rock bottom. Ground water estimated $0.2 \mathrm{ft}$ below MSL.

I-1684. Shelly Bay, 7.25 ft

$1820 \pm 120$

Peat from Shelly Bay $\left(32^{\circ} 19^{\prime} 54^{\prime \prime}\right.$ N Lat, $64^{\circ} 44^{\prime} 15^{\prime \prime}$ W Long), from depth -7.4 to $7.79 \mathrm{ft}$ from $1.0 \mathrm{ft}$ above rock bottom.

I-1685. Long Bay, $2.45 \mathrm{ft}$

$880 \pm 120$

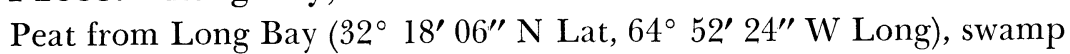
separated from sea by shelly sandbeach. From depth -1.2 to $-1.8 \mathrm{ft}$ from $6.4 \mathrm{ft}$ above rock bottom. Ground water estimated $0.86 \mathrm{ft}$ above MSL.

\section{I-1686. Long Bay, 8.45 ft}

$3900 \pm 120$

1950 в.c.

Organic silt from Long Bay $\left(32^{\circ} 18^{\prime} 06^{\prime \prime} \mathrm{N}\right.$ Lat, $64^{\circ} 52^{\prime} 24^{\prime \prime} \mathrm{W}$ Long), from depth -7.2 to $-7.8 \mathrm{ft}$ from $0.4 \mathrm{ft}$ above rock bottom.

\section{I-1762. Long Bay, A-11.4 ft}

$3600 \pm 120$

1650 B.c.

Silty peat from Long Bay ( $32^{\circ} 18^{\prime} 06^{\prime \prime} \mathrm{N}$ Lat, $64^{\circ} 52^{\prime} 24^{\prime \prime}$ W Long), from depth -9.8 to $10.4 \mathrm{ft}$ from $2 \mathrm{ft}$ above rock bottom.

\section{I-1763. Long Bay, B-11.45 ft}

$3930 \pm 120$

Organic silt from Long Bay $\left(32^{\circ} 18^{\prime} 06^{\prime \prime} \mathrm{N}\right.$ Lat, $64^{\circ} 52^{\prime} 24^{\prime \prime} \mathrm{W}$ Long), from depth -10.2 to $-10.7 \mathrm{ft}$ from immediately below I-1762. 
I-1764. Long Bay, C-4.05 ft

$1510 \pm 110$

Peat from Long Bay ( $32^{\circ} 18^{\prime} 06^{\prime \prime} \mathrm{N}$ Lat, $64^{\circ} 52^{\prime} 24^{\prime \prime} \mathrm{W}$ Long), from depth -2.8 to $-3.3 \mathrm{ft}$.

\section{I-1765. Long Bay, D-4.35 ft}

$1440 \pm 110$

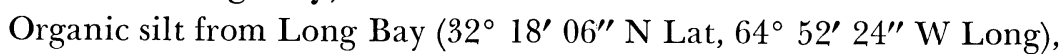
from depth -3.2 to $-3.5 \mathrm{ft}$ from immediately below I-1764.

I-1969. Long Bay, $\mathbf{E}$

$1210 \pm 95$

Peat from Long Bay (32 $18^{\prime} 06^{\prime \prime} \mathrm{N}$ Lat, $64^{\circ} 52^{\prime} 24^{\prime \prime} \mathrm{W}$ Long), from depth 1.75 to $2.25 \mathrm{ft}$ below MSL from $1.1 \mathrm{ft}$ above rock bottom.

\section{I-1970. Long Bay, F}

$2050 \pm 105$

Calcareous sand from Long Bay $\left(32^{\circ} 18^{\prime} 06^{\prime \prime} \mathrm{N}\right.$ Lat, $64^{\circ} 52^{\prime} 24^{\prime \prime} \mathrm{W}$ Long), from depth 2.15 to $2.55 \mathrm{ft}$ below MSL from $0.5 \mathrm{ft}$ above rock bottom.

\section{I-1971. Long Bay, G}

$2440 \pm 110$

Peat from Long Bay ( $32^{\circ} 18^{\prime} 06^{\prime \prime} \mathrm{N}$ Lat, $64^{\circ} 52^{\prime} 24^{\prime \prime} \mathrm{W}$ Long), from depth 3.95 to $4.35 \mathrm{ft}$ below MSL from $1.4 \mathrm{ft}$ above rock bottom.

\section{I-1972. Long Bay, H}

$2760 \pm 100$

Calcareous sand from Long Bay $\left(32^{\circ} 18^{\prime} 06^{\prime \prime} \mathrm{N}\right.$ Lat, $64^{\circ} 52^{\prime} 24^{\prime \prime} \mathrm{W}$ Long), from depth 4.35 to $4.75 \mathrm{ft}$ below MSL from $1.0 \mathrm{ft}$ above rock bottom.

\section{I-1973. Long Bay, I}

$$
2530 \pm 100
$$

Peat from Long Bay ( $32^{\circ} 18^{\prime} 06^{\prime \prime} \mathrm{N}$ Lat, $64^{\circ} 52^{\prime} 24^{\prime \prime} \mathrm{W}$ Long), from depth 5.15 to $5.65 \mathrm{ft}$ below MSL from $0.6 \mathrm{ft}$ above rock bottom.

\section{I-1974. Long Bay, J}

$$
2590 \pm 100
$$

Calcareous silt from Long Bay $\left(32^{\circ} 18^{\prime} 06^{\prime \prime} \mathrm{N}\right.$ Lat, 64 $52^{\prime} 24^{\prime \prime} \mathrm{W}$ Long), from depth 5.75 to $6.15 \mathrm{ft}$ below MSL from $0 \mathrm{ft}$ above rock bottom.

\section{I-1975. Long Bay, K}

$2690 \pm 90$

Peat from Long Bay ( $32^{\circ} 18^{\prime} 06^{\prime \prime} \mathrm{N}$ Lat, $64^{\circ} 52^{\prime} 24^{\prime \prime} \mathrm{W}$ Long), from depth 6.15 to $6.55 \mathrm{ft}$ below MSL from $1.5 \mathrm{ft}$ above rock bottom. 
I-1976. Long Bay, $L$

1220 B.c.

Calcareous silt from Long Bay $\left(32^{\circ} 18^{\prime} 06^{\prime \prime} \mathrm{N}\right.$ Lat, $64^{\circ} 52^{\prime} 24^{\prime \prime} \mathrm{W}$ Long), from depth 6.65 to $7.05 \mathrm{ft}$ below MSL from $1.0 \mathrm{ft}$ above rock bottom.

\section{PHYSICAL GEOGRAPHY SAMPLES}

\section{A. Canadian North West Territories}

\section{East Baffin Island series}

Samples from various locations on Baffin Island, NW Territories. Coll. and subm. during 1965 and 1966 by members of eog. Branch, Dept. of Energy, Mines, and Resources (formerly Mines and Tech. Surveys), Ottawa, Canada.

1-1812. Cape Christian Cliffs, No. 1

Marine shells (Astarte, Mya), fragments, and (Hiatella arctica, Linné) from $21 \mathrm{~km} \mathrm{NW}$ of Clyde settlement (70 $38.6^{\prime} \mathrm{N}$ Lat, $68^{\circ} 42.4^{\prime} \mathrm{W}$ Long). From exposure in sea cliffs at $5.6 \mathrm{~m}$ above sea level. Coll. and subm. 1965 by O. H. L $\phi$ ken (L $\phi$ ken, 1966; Andrews, 1966b).

I-1813. Cape Christian Cliffs, No. 2

Marine shells (Serripes groenlandicum, Bruguière), (Mya truncata, Linné), and (Hiatella arctica, Linné) from ca. $17.5 \mathrm{~km}$ NNE of Clyde settlement $\left(70^{\circ} 36.2^{\prime} \mathrm{N}\right.$ Lat, $68^{\circ} 28.1^{\prime} \mathrm{W}$ Long). From exposure in sea cliffs at $13.4 \mathrm{~m}$ above sea level. Coll. and subm. 1965 by O. H. L $\phi$ ken. Comment (O.H.L.): sample redated by Yale (Y-1702, >50,000) (L $\phi$ ken, 1966; Andrews, 1966b).

\section{I-1814. Cape Aston}

Marine shells from clay stratum in delta, considered in situ $\left(69^{\circ} 54.6^{\prime}\right.$ $\mathrm{N}$ Lat, $67^{\circ} 34.2^{\prime} \mathrm{W}$ Long). Elev. of site $65 \mathrm{~m}$ above sea level, delta surface lies $84 \mathrm{~m}$ above sea level. Coll. and subm. 1965 by O. H. L $\phi$ ken (L $\phi$ ken, 1966; Andrews, 1966b).

I-1829. McBeth Fiord

Marine shell fragments from moraine ridge well above local marine limit, $24.5 \mathrm{~m}$ above sea level, $\mathrm{N}$ side of McBeth Fiord (69 $44.2^{\prime} \mathrm{N}$ Lat, $67^{\circ} 2^{\prime} \mathrm{W}$ Long). Coll. and subm. 1965 by O. H. L $\phi$ ken. Comment (O.H.L.): shells assumed to have been carried up from sea bed during glacial readvance (L $\phi$ ken, 1966; Andrews, 1966b).

\section{I-1832. Clyde Fiord}

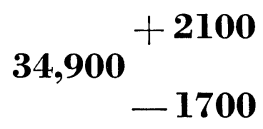

Marine shells from lateral moraine of readvance at $51 \mathrm{~m}$ above sea level, N side of outer Clyde Fiord ( $70^{\circ} 17^{\prime} \mathrm{N}$ Lat, $69^{\circ} 00^{\prime} \mathrm{W}$ Long). Coll. 
and subm. 1965 by J. E. Smith. Comment (J.E.S.): dates from other samples in area indicate date is probably minimum (L $\phi$ ken, 1966; Andrews, 1966b).

I-1816. Cape Christian Cliffs, No. 3

Marine shells (Hiatella arctica, Linné) from coastal cliff exposure $2 \mathrm{~m}$ above sea level, $17.5 \mathrm{~km}$ NNE of Clyde settlement $\left(70^{\circ} 36.2^{\prime} \mathrm{N}\right.$ Lat, $62^{\circ} 28.1^{\prime}$ W Long). Coll. and subm. 1965 by O. H. L $\phi$ ken.

General Comment (O.H.L.): 2 samples redated by Yale indicate all samples in this series are probably of great age and are beyond range of finite dating. They show that ice-free areas existed along outer NE coast of Baffin Island for at least 54,000 yrs although outlet glaciers have pushed beyond fiord mouths more recently than this (L $\phi$ ken, 1966; Andrews, 1966b).

\section{Baffin Island Lake series}

$785 \pm 105$

I-1834. Flint Lake

A.D. 1165

Peat from continuous peat layer overlain by $1 \mathrm{~m}$ marine clay, Flint Lake (69 $16^{\prime} \mathrm{N}$ Lat, $74^{\circ} 22^{\prime} 30^{\prime \prime} \mathrm{W}$ Long), Baffin Island, N.W.T. Coll. and subm. 1965 by J. T. Andrews. Comment (J.T.A.): vegetation appeared in situ and indicated transgression at ca. $41 \mathrm{~m}$ above sea level. Date indicates layer was overrun by mass movement despite lack of structures in overlying clay (Andrews, 1966b).

\section{I-1833. Gillian Lake}

$5270 \pm 140$

Marine shells from $5 \mathrm{~cm}$ sand layer overlain by deltaic deposits, Gillian Lake (69 $28^{\prime} \mathrm{N}$ Lat, $75^{\circ} 31^{\prime} \mathrm{W}$ Long), Baffin Island, N.W.T. Coll. and subm. 1965 by C. A. M. King and J. T. Philpot. Comment (J.T.P.): delta surface lies at $67 \mathrm{~m}$ above sea level. Date indicates sea invaded Gillian Lake basin; date also compares well with I-1244 (Isotopes V) from similar elev. along this portion of Baffin coast (Andrews, 1966b).

\section{I-1831. Piling Lake, No. 1}

Marine shells (Mya truncata, Linné) and (Hiatella arctica, Linné) from pit in estuarine silts at $64 \mathrm{~m}$ above sea level, Piling Lake $\left(69^{\circ} 07^{\prime} \mathrm{N}\right.$ Lat, $75^{\circ} 02^{\prime} \mathrm{W}$ Long), Baffin Island, N.W.T. Coll. and subm. 1965 by J. T. Andrews. Comment (J.T.A.): marine limit in area clearly marked at $83 \mathrm{~m}$ above sea level. Date indicates this feature probably dates from ca. 6,000 B.P., on distal side of Isortoq phase moraines dated ca. 6.700 B.P. (Andrews, 1966a; 1966b).

\section{I-1830. Piling Lake, No. 2} (Astarte borealis, Schumacher), (Astarte montagui, Dillwyn) forma typica, 
from beach foreset beds exposed in stream cut at $2.5 \mathrm{~m}$ above sea level, Piling Lake $\left(69^{\circ} 06^{\prime} \mathrm{N}\right.$ Lat, $74^{\circ} 47^{\prime} \mathrm{W}$ Long), Baffin Island, N.W.T. Coll. and subm. 1965 by J. T. Andrews. Comment (J.T.A.): sample dates relative sea level at ca. 5 to $7 \mathrm{~m}$ above present sea level and indicates isostatic readjustment of $\mathrm{W}$ Baffin Island might still be occurring at rate of $0.4 \mathrm{~m} /$ century (Andrews, 1966b).

\section{Baffin Island Fiord series}

\section{I-1835. Clyde Fiord}

$1860 \pm 110$

Peat from stream cut along distal side of glacio-marine delta showing 5-m-thick peat sequence in inner Clyde Fiord ( $69^{\circ} 51^{\prime} \mathrm{N}$ Lat, $70^{\circ} 28^{\prime}$ W Long), Baffin Island, N.W.T. Coll. and subm. 1965 by D. M. Barnett. Comment (D.M.B.): sample from bottom of longest unbroken sequence and not from base of deposit from which it may be separated by erosional hiatus (Andrews, 1966b).

\section{I-1983. Dexterity Fiord}

$8180 \pm 130$

Marine shells (Mya Truncata, Linné) and (Hiatella arctica, Linné) in situ from stratified deltaic beds $39 \mathrm{~m}$ above sea level, Duart Bay Dexterity Fiord ( $71^{\circ} 20^{\prime} 50^{\prime \prime} \mathrm{N}$ Lat, $72^{\circ} 52^{\prime} 50^{\prime \prime} \mathrm{W}$ Long), Baffin Island, N.W.T. Coll. 1963 by D. A. Harrison; subm. 1966 by J. T. Andrews. Comment (J.T.A.): date indicates outer part of Dexterity Fiord may have been ice-free by ca. 9,000 в.P. (Harrison, 1964).

\section{I-1931. Sam Ford Fiord, No. 2}

$4920 \pm 180$

Marine shells from sand/silt beds in beach deposit $15.7 \mathrm{~m}$ above sea level at Sam Ford Fiord ( $70^{\circ} 01.3^{\prime} \mathrm{N}$ Lat, $71^{\circ} 32.8^{\prime} \mathrm{W}$ Long), Baffin Island, N.W.T. Coll. 1964 and subm. 1966 by O. H. Lфken. Comment (O.H.L.): same sample site as I-1670 $(4770 \pm 140$, Isotopes V) which did not fit into expected pattern of elev. and time. Samples agree within 2 standard errors. Best estimate for site is now $4845 \pm 228$ B.P. (Andrews, 1966b).

\section{I-1933. Sam Ford Fiord, No. 1}

$$
8210 \pm 130
$$

6260 B.c.

Marine shells from boulder-rich marine clays that were involved in ice advance, $19 \mathrm{~m}$ above sea level at Sam Ford Fiord $\left(70^{\circ} 20^{\prime} \mathrm{N} \mathrm{Lat}, 71^{\circ}\right.$ 08' W Long), Baffin Island, N.W.T. Coll. 1965 and subm. 1966 by J. E. Smith. Comment (J.E.S.): studies on lateral deposits along Sam Ford Fiord indicate sample dates major moraine phase traceable to head of Clyde Fiord. Date indicated temporal association of this moraine with Cockburn moraines of Baffin Island and McAlpine-Arctic mainland moraines all dated ca. 8,300 B.P. (Andrews, 1966b). 
I-1934. Inugsuin Fiord

$6560 \pm 125$

Marine shells (Mytilus edulis, Linné), (Mya Truncata, Linné), and (Hiatella arctica, Linné), from stratified sand/silt layer, 8.5 to $11.0 \mathrm{~m}$ above sea level at Inugsuin Fiord (69 $56^{\prime} \mathrm{N}$ Lat, $68^{\circ} 40^{\prime} \mathrm{W}$ Long), Baffin Island, N.W.T. Coll. 1965 by D. A. Harrison; subm. 1966 by O. H. L $\phi$ ken. Comment (O.H.L.): sample dates relative sea level at $11.0 \mathrm{~m}$ above present sea level. Marine limit in vicinity is ca. $25 \mathrm{~m}$ above sea level.

\section{B. Great Britain}

I-1909. Bride moraine, Great Britain

Marine shells (Turitella and Macoma) from sea cliff exposure in Bride moraine, Isle of Man (54 $20^{\prime} \mathrm{N}$ Lat, $04^{\circ} 20^{\prime} \mathrm{W}$ Long), Great Britain. Coll. 1964 by C. A. M. King; subm. 1966 by J. T. Andrews. Comment (J.T.A.): sample weighed 6 gms, mixed with coal gas for counting. Date older than expected, may indicate that Bride moraine represents 2 phases. Upper section of moraine is frequently linked with Scottish readvance.

\section{ARCHAEOLOGIC SAMPLES}

\section{A. Western United States}

\section{Port Moller series, Alaska}

Charcoal from Hot Springs shell midden $\left(55^{\circ} 53^{\prime} \mathrm{N}\right.$ Lat, $160^{\circ} 30^{\prime} \mathrm{W}$ Long), W side of Port Moller (bay), Alaska. Coll. 1960 by S. Sugihara, Meiji Univ., subm. 1964 by C. S. Chard, Univ. of Wisconsin, Madison, Wisconsin.

\section{I-1507. Trench I, bottom level}

$2680 \pm 250$

730 B.C.

I-1508. Trench II, Section 2

$2960 \pm 320$

From bottom of cultural deposit.

General Comment (C.S.C.): dates agree with time depth now known for human occupation elsewhere on Alaska Peninsula and in Aleutians (De Laguna, 1934; Workman, 1965).

\section{I-1918. Sanders, Arizona}

$740 \pm 95$

Charcoal flecks mixed with fluvial sand and roots off floor of Pithouse 3, from Sanders ( $35^{\circ} 14^{\prime} \mathrm{N}$ Lat, $109^{\circ} 22^{\prime} \mathrm{W}$ Long), Arizona. Coll. and subm. 1965 by G. J. Gumerman, Mus. of N Arizona, Flagstaff, Arizona. Comment (G.J.G.): date appears too late for preceramic site assigned to Basketmaker II tradition (A.D. 1 to 500) because of artifact type and architecture. 


\section{I-1928. Kern County, California}

Fresh water clam shell (Anadonta nuttalliana, Lea) at foot of Buena Vista Hills, elev. 295 to $304 \mathrm{ft}$ above sea level, on shore line of old Buena Vista Lake $\left(35^{\circ} 10^{\prime} 55^{\prime \prime} \mathrm{N}\right.$ Lat, $119^{\circ} 21^{\prime} 20^{\prime \prime} \mathrm{W}$ Long), Kern County, California. From cultural deposit 280 to $340 \mathrm{~cm}$ below ground surface (Gifford and Schenck, 1926; Wedel, 1941). Coll. 1965 by J. W. Grossman and John Waller; subm. 1965 by R. L. Burtner, Chevron Research Co. Comment (J.W.G.): date suggests possible affiliations with San Dieguito and Mohave complexes.

\section{I-2007. Bare Ranch, California}

$2130 \pm 105$ 180 B.C.

Charcoal from $1.80 \mathrm{~m}$ depth, elev. $4550 \mathrm{ft}$, Bare Ranch $\left(41^{\circ} 12^{\prime} \mathrm{N}\right.$ Lat $120^{\circ} \mathrm{l}^{\prime} \mathrm{W}$ Long), Lassen County, California. From 1 of series of circular house floors exposed during construction. Site is known locally as Chief Winnemucca's camp. Coll. 1965 by W. A. Davis and Don Tuohy; subm. 1966 by W. A. Davis, Univ. of Nevada, Reno, Nevada. Comment (W.A.D.): site was tested by J. F. O'Connell, Univ. of California, summer of 1966, who reported (oral commun.) that dated level yielded cultural material corresponding to Early Lovelock phase.

\section{I-1112. Mesa Verde, Colorado}

A.D. 1060

$\mathbf{8 9 0} \pm \mathbf{1 5 0}$

Charcoal from cist in 1 of deepest caves in Mesa Verde Natl. Park, $\mathrm{W}$ side of Long Canyon ( $37^{\circ} 11^{\prime} 15^{\prime \prime} \mathrm{N}$ Lat, $108^{\circ} 31^{\prime} 30^{\prime \prime} \mathrm{W}$ Long), Wetherill Mesa, Colorado. From site 1291, ca. $1.5 \mathrm{ft}$ depth, Mesa Verde Mus. Cat. No. 41285/718, Field Specimen Cat. No. 103. Coll. 1963 by J. D. Swannack, Jr.; subm. 1963 by D. Osborne, U.S. Dept. of Interior, Natl. Park Service. Comment (D.O.): site 1291 has longest history of occupation in park from Basketmaker III through Pueblo III period. Best estimate is that cist was constructed during Basketmaker III period, dated in this park from ca. A.D. 600 to 700 . Charcoal was probably washed in from Pueblo II occupation.

\section{Spooner Lake series, Nevada}

Charcoal from bedrock mortar and bedrock metate site at Spooner Lake (39 $6^{\prime} \mathrm{N}$ Lat, $119^{\circ} 54^{\prime} \mathrm{W}$ Long), Douglas County, Nevada. Site is strategically located at pass on mule deer migration route, elev. $7000 \mathrm{ft}$. Culture-bearing deposit is homogeneous granitic sands and clays resting on granite rock which is rapidly decomposing along contact zone. Coll. 1965 and subm. 1966 by W. A. Davis. Beach complex. Comment (W.A.D.): dates occurrence of Desert Side- 
Notched projectile points (Sierra sub-type) and bedrock mortar pestle (Baumhoff and Byrne, 1959).

\section{I-1996. No. 2, Cat. No. 199}

$$
1800 \pm 100
$$

From Pit No. 11, 22 to $42 \mathrm{~cm}$ depth, composite. Spooner III component, late phase of Martis complex.

\section{I-1997. No. 3, Cat. No. 228}

$$
1890 \pm 100
$$

From Pit No. 12, $25 \mathrm{~cm}$ depth. From possible post associated with slab metate and biface mano. Spooner III component; late phase of Martis complex. Comment (W.A.D.): may date earliest appearance of Martis Corner-Notched projectile points.

\section{I-1998. No. 4, Cat. No. 213}

$$
\begin{aligned}
& 3050 \pm 105 \\
& 1100 \text { B.c. }
\end{aligned}
$$

From Pit No. 11, 62 to $82 \mathrm{~cm}$ depth, composite. Spooner II component, early phase of Martis complex.

\section{I-1999. No. 5, Cat. No. 217}

$$
2960 \pm 195
$$

From Pit No. 11, 82 to $102 \mathrm{~cm}$ depth, composite. Spooner II component, early phase of Martis complex. Comment (W.A.D.): younger date than I-1998 probably due to occupation mixture. I-1998 and I-1999 may date introduction of Rose Spring Corner-Notched projectile points.

I-2000. No. 6, Cat. No. 535

$$
4920 \pm 120
$$

From Pit No. 26, charcoal lens $45 \mathrm{~cm}$ depth. Comment (W.A.D.): "wide-stem" Pinto point was recovered ca. $1 \mathrm{~m}$ distant and $5 \mathrm{~cm}$ above lens (Harrington, 1957).

\section{I-2001. No. 7, Cat. No. 539}

$7100 \pm 140$ 5150 B.c.

From Pit No. 26, 55 to $75 \mathrm{~cm}$ depth, composite. Comment (W.A.D.): data indicates possible existence of buried site $\mathrm{E}$ of bedrock mortar boulders.

\section{I-2002. No. 8, Cat. No. 526}

$$
410 \pm 95
$$

From Pit No. 25, 28 to $48 \mathrm{~cm}$ depth, composite. From square in S-center of bedrock mortar area. Spooner IV component, Kings Beach complex.

I-2003. No. 9, Cat. No. 273

$$
1720 \pm 100
$$

From Pit No. 13, 10 to $30 \mathrm{~cm}$ depth, composite. On NE edge of bedrock mortar area. Spooner III component, late phase of Martis complex. Comment (W.A.D.): dates occurrence of thin portable metates. 
I-2004. No. 10, Cat. No. 273

From Pit No. 14, 28 to $48 \mathrm{~cm}$ depth, inverted deposit. Composite from $\mathrm{S}$ edge of bedrock mortar area. Spooner V component, Washo occupation phase. Comment (W.A.D.): submitted as check on extent of post-contact disturbances.

General Comment (W.A.D.): premature summary based on field data (Davis, 1966) tentatively reported that artifact inventory represented "relatively pure component" protohistoric in age. Detailed laboratory analysis did not support assumption. Index artifact type distribution anomalies plus post-contact disturbances made thorough checking by radiocarbon dating mandatory. Dates are internally consistent when correlated with excavation and laboratory data; they provide provisional culture chronology for Lake Tahoe region of Sierra Nevada Mts.

I-2006. Jacks Valley, Nevada

Charcoal from rock-oven hearth, Jacks Valley $\left(39^{\circ} 5^{\prime} \mathrm{N}\right.$ Lat, $119^{\circ}$ $47^{\prime}$ W Long), Douglas County, Nevada. Elev. $4880 \mathrm{ft}$, cultural feature \#2, Cat. No. 262, $15 \mathrm{~cm}$ depth. Jacks Valley II component, late phase of Kings Beach complex. Coll. 1965 and subm. 1966 by W. A. Davis.

\section{I-1713. Rio Puerco, New Mexico}

$1000 \pm 115$

Charred corn from 20 in. depth, $\mathrm{E}$ bank of Rio Puerco, ca. $1 \mathrm{mi} \mathrm{N}$ of Highway 66, $18 \mathrm{mi} \mathrm{W}$ of Albuquerque ( $35^{\circ} \mathrm{N}$ Lat, $102^{\circ} 15^{\prime \prime} \mathrm{W}$ Long), New Mexico. Many joined ears of corn were found encased by flat stones, all charred but not consumed, overlain by ca. $1 \mathrm{ft}$ or black volcanic sand. Coll. 1961 by H. C. Neugebauer; subm. 1965 by C. H. Hapgood, Keene State College, New Hampshire. Comment (C.H.H.): date indicates volcanic eruptions in area were more recent than supposed.

\section{Brewster series, Okanogan County, Washington}

Charcoal from right bank of Columbia R., downstream from town of Brewster, Okanogan County, Washington.

I-2032. Neff Site, 450K58, No. 279

$$
3020 \pm 150
$$

Charcoal from small scattered hearth $1.6 \mathrm{~m}$ below surface $\left(48^{\circ} 4^{\prime} 40^{\prime \prime}\right.$ $\mathrm{N}$ Lat, $119^{\circ} 50^{\prime} \mathrm{W}$ Long), ca. $3 \mathrm{mi}$ downstream from Brewster. Stratum also contained lanceloate and large basal-notched projectile points (Collier, Hudson, and Ford, 1942; Osborne, Crabtree, and Bryan, 1952; Swanson, 1959). Coll. 1966 by D. Browman; subm. 1966 by G. F. Grabert, Univ. of Washington, Dept. of Anthropol., Seattle, Washington.

I-2033. Hymer Site, $450 K 78$, No. 459 
terrace above active flood plain. Sample associated with fire-broken rocks, post molds, fish-bone, and fresh-water mussel (Margaritifera) shell. Coll. 1966 by D. Cole subm. 1966 by G. F. Grabert.

General Comment (G.F.B.): dates seem internally consistent with types of artifactual material, and in their external relationships to similar sites. Artifacts from both sites (I-2032 and I-2033) show similarities to those of comparable dates from Middle Columbia Region.

\section{B. Central and Eastern United States}

\section{I-2308. R-16, Monks Mound, Illinois}

$$
1020 \pm 100
$$

Wood from 3rd terrace, E $180-\mathrm{N} 139$, Hole No. 7, Monks Mound Ms-38 (38 $37^{\prime} \mathrm{N}$ Lat, $90^{\circ} 04^{\prime} \mathrm{W}$ Long), Cahokia site, Madison County, Illinois. Taken by Shelby Tube Coring at depth $68 \mathrm{ft}$, apparent living surface $29 \mathrm{ft}$ above base of mound. Coll. and subm. 1966 by J. W. Porter and N. A. Reed, Washington Univ., St. Louis. Comment (J.W.P.): sample establishes date for 1 of early construction stages of mound, to be compared with A.D. $1120 \pm 100$ for last known living stage at $96 \mathrm{ft}$ above base, $4 \mathrm{ft}$ below present surface.

\section{Effigy Mounds series, Iowa}

Hickory charcoal from cremation zone, 38 to $40 \mathrm{in.} \mathrm{depth} \mathrm{in} \mathrm{conical}$ mound 12, sec. 27, T96 N, R3 W, Effigy Mounds Natl. Monument $\left(43^{\circ}\right.$ $5^{\prime} \mathrm{N}$ Lat, $91^{\circ} 11^{\prime} \mathrm{W}$ Long), Allamakee County, Iowa. Soil profile above zone is weakly developed, cremation zone is in buried B horizon $32+$ in. Coll. 1960 by R. B. Parsons and W. H. Scholtes; subm. 1961 by R. V. Ruhe.

\section{I-295. Effigy Mounds, No. 1}

$$
1740 \pm 110
$$

$$
1960 \pm 90
$$

I-296. Effigy Mounds, No. 2

10 B.c.

\section{Knox County series, Nebraska}

Charcoal, carbon, and ash from Knox County, Nebraska. Coll. 1963 and subm. 1964 by R. D. Gant, South Dakota Mus., State Univ. of South Dakota, Vermillion, South Dakota.

\section{I-1308. Knox County, No. 1}

$$
\begin{aligned}
2660 & \pm 110 \\
710 \text { B.C. } &
\end{aligned}
$$

Charcoal from depth 4.5 to $5.0 \mathrm{ft}$, SE $1 / 4$, sec. 14, T33 N, R2 W, Knox County $\left(42^{\circ} 30^{\prime} \mathrm{N}\right.$ Lat, $97^{\circ} 45^{\prime} \mathrm{W}$ Long), Nebraska. From layer of refuse sandwiched between thick strata of dark brown humus. Associated with flakes, cores, a single point fragment, bison bones, and a rim sherd (Howard and Gant, 1966). Comment (R.D.G.): date should establish early horizon for Plains Woodland on central Plains. 


\section{I-1309. Knox County, No. 2}

Carbon from depth $5.5 \mathrm{ft}$, SE 1/4, sec. 14, T33 N, R2 W, Knox County ( $42^{\circ} 30^{\prime} \mathrm{N}$ Lat, $97^{\circ} 40^{\prime} \mathrm{W}$ Long), Nebraska. Associated with unworked flakes, mid-section of projectile point, blade fragments, and polished antler tine (Howard and Gant, 1966). Comment (R.D.G.): date is close to that of Sample No. 1 (I-1308, this list) and may indicate separation of Plains Archaic from Plains Woodland horizon.

\section{I-1310. Knox County, No. 3}

$2960 \pm 125$

Organic material (ash and carbon) from fire hearth at depth 16.5 $\mathrm{ft}, \mathrm{SE} 1 / 4$, sec. 14 , T33 N, R2 W, Knox County $\left(42^{\circ} 30^{\prime} \mathrm{N}\right.$ Lat, $97^{\circ} 40^{\prime}$ W Long), Nebraska. Artifacts and cultural detritus found at this depth are similar to material culture recovery from Occupation Level I at Signal Butte in NE Nebraska (Strong, 1935; Howard and Gant, 1966). Comment (R.D.G.): date should be assigned to Plains Archiac Tradition dating corner-notched "fish-tailed" style projectile points.

\section{I-1345. Ocala National Forest, Florida}

$3640 \pm 110$

Shells (Viviparus georgianus Lea) from "Midden No. 1" at 12 in. depth, Ocala Natl. Forest ( $29^{\circ} 5^{\prime} 30^{\prime \prime} \mathrm{N}$ Lat, $81^{\circ} 31^{\prime} \mathrm{W}$ Long), NE Lake City, Florida. Coll. and subm. 1964 by R. P. Bullen, Univ. of Florida, Florida State Mus., Gainesville, Florida. Comment (R.P.B.): sample taken to compare date with those of neighboring midden. Date as anticipated was younger but may not be reliable due to $\mathrm{CaCO}_{3}$ in water where shells grew (Bullen and Bryant, 1965).

\section{Crystal River series, Florida}

Charcoal from Crystal R. (28 $54^{\prime} 15^{\prime \prime} \mathrm{N}$ Lat, $82^{\circ} 37^{\prime} 45^{\prime \prime} \mathrm{W}$ Long), Citrus City, Florida. Sample I-1365 coll. 1960, other samples coll. 1964; all subm. 1964 by R. P. Bullen.

\section{I-1365. CR 1-1}

$$
1310 \pm 100
$$

From charcoal "hearth" or "fireplace" $19 \mathrm{ft}$ below top of large temple mound. Comment (R.P.B.): date is reasonable for construction of lower part of this early temple mound.

\section{I-1366. CR 2-3}

$$
1870 \pm 130
$$

From midden, 18 to 24 in. depth, associated with fabric or textile in pressed and plain sherds. Comment (R.P.B.): date seems early but is about right for close of Deptford period. 


\section{I-1367. CR 3-6}

$1750 \pm 130$

From midden, 54 to 60 in. depth, associated with Deptford Linear check and simple stamped plus Pasco Plain sherds. Comment (R.P.B.): date is about right for close of late Deptford in this area.

\section{I-1368. CR 4-7}

From base of main burial mound at Crystal R. site. Comment (R.P.B.): sample believed contaminated by charcoal from fires during earlier excavation.

\section{I-1464. Ci-1}

$$
\begin{array}{r}
1420 \\
\text { A.D. } 530
\end{array}
$$

From path of food remains, 15 to 18 in. depth, leading from bottom of recently discovered stele to bottom of nearby rock. Comment (R.P.B.): date indicates erection of stele. Ramp of early temple mound (I-1365, this series) points almost directly toward this stele.

\section{I-1916. Crystal River No. 6, Florida}

Charcoal from N side Crystal R. (28 $54^{\prime} 30^{\prime \prime} \mathrm{N}$ Lat, $82^{\circ} 37^{\prime} 35^{\prime \prime \prime} \mathrm{W}$ Long), peninsula Florida. From pit in basal black zone under main burial mound. Coll. and subm. 1965 by R. P. Bullen. Comment (R.P.B.): zone is presumably 1st part of construction of main burial mound at Crystal R. Date implies large burial mound was built first and high conical part was constructed later upon platform.

\section{I-1661. Polk City, No. 1, Florida}

$3040 \pm 115$

Wood (American Cyanamid) from derelict Indian canoe below $5 \mathrm{ft}$ of peat and muck, NE of Lakeland, Polk City (28 $7^{\prime} \mathrm{N}$ Lat, $81^{\circ} 55^{\prime} 30^{\prime \prime}$ W Long), Florida. Coll. and subm. 1965 by R. P. Bullen. Comment (R.P.B.): date indicates dugout canoes were in use $3000 \mathrm{yr}$ ago.

\section{Mosquito Lagoon series, Florida}

Charcoal from Mosquito Lagoon (28 $49^{\prime \prime} \mathrm{N}$ Lat, $80^{\circ} 49^{\prime} \mathrm{W}$ Long), SE of Oak Hill, Volusia City, Florida. Coll. 1963 by R. P. Bullen and W. J. Bryant; subm. 1965 by R. P. Bullen.

\section{I-1663. Test 1}

From 36 to 42 in. depth, Midden Test 1.

I-1664. Test 2

From $5 \mathrm{ft}$ depth, Midden Test 2, associated with St. Johns Plain

$955 \pm 110$

A.D. 995

$$
1680 \pm 220
$$

A.D. 270 pottery. 
General Comment (J.P.B.): dates confirm previous estimates of time of St. Johns I A late period.

\section{Burtine Island series, Florida}

Shells and charcoal from Burtine Island $\left(28^{\circ} 59^{\prime} 30^{\prime \prime} \mathrm{N}\right.$ Lat, $82^{\circ} 44^{\prime}$ 45" W Long), W coast of Florida. Coll. and subm. 1965 and 1966 by R. P. Bullen.

\section{I-1913. Burtine Island, Site A \\ $2630 \pm 100$}

Melongena shell from 18 to 24 in. depth. Comment (R.P.B.): date pertains to undecorated ceramic period of Florida Gulf Coast. Apparently it is before instead of after Weeden Island period.

\section{I-1914. Burtine Island, Site C}

$1505 \pm 95$

Venus clam shell from 18 to 24 in depth. Comment (R.P.B.): sample associated with ceramics of Perico period and Deptford simple stamped sherds. Deptford period may have lasted later in this area.

\section{I-1915. Burtine Island, Site D}

$235 \pm 100$

Charcoal from 24 to 27 in. depth. Comment (R.P.B.): charcoal must have been from stump which burnt in ground.

\section{I-1961. Burtine D, Sample 4}

$1965 \pm 95$

15 в.c.

Busycon shell from 36 to 43 in. depth in shell midden. Comment (R.P.B.): date indicates shell from Deptford period.

\section{I-2010. Burtine $\mathrm{C}, 12-18$ in.}

$325 \pm 90$

Charcoal from 12 to 18 in. depth in shell midden. Comment (R.P.B.): date is incongruent with archaeology. Must indicate disturbance of undetected post hole or pit.

\section{I-1988. Burtine C, Test 2}

$3390 \pm 110$

Melongena corona shell from 6 to 12 in. depth in shell midden. Comment (R.P.B.): date incompatible with archaeology, probably because of antique carbon from limestone in solution in shells environment.

\section{I-1965. Barnstable, Massachusetts}

$$
625 \pm 95
$$

Carbonized wood from shell heap at Sandy Neck, Barnstable $\left(41^{\circ}\right.$ $44^{\prime} 06^{\prime \prime} \mathrm{N}$ Lat, $70^{\circ} 22^{\prime} 20^{\prime \prime} \mathrm{W}$ Long), Massachusetts. From surface exposure of presumed Indian camp site. Assoc. with pottery fragments and broken clam shells. Coll. and subm. 1965 by A. C. Redfield. 


\section{I-2399. Nahrwold site, Middleburgh, New York}

$640 \pm 95$

Charcoal from Nahrwold site $\left(42^{\circ} 34^{\prime} 30^{\prime \prime} \mathrm{N}\right.$ Lat, $74^{\circ} 20^{\prime} 37^{\prime \prime} \mathrm{W}$ Long), town of Middleburgh, Schoharie County, New York. Charcoal taken from storage pit, assoc. with much bone and flint refuse, a sinewstone, flint knife, and potsherds of Castle Creek Beaded type (Ritchie, 1965). Coll. and subm. 1966 by W. A. Ritchie, New York State Mus. and Sci. Serv., New York. Comment (W.A.R.): date agrees with very late Owasco period just preceding transition into early lroquois Oak Hill horizon.

590 B.C.

Charcoal from Weinman site $\left(43^{\circ} 27^{\prime} 30^{\prime \prime} \mathrm{N}\right.$ Lat, $73^{\circ} 34^{\prime} 18^{\prime \prime} \mathrm{W}$ Long), Assembly Point, Lake George, Warren County, New York. Sample from base of Feature 16, large oval pit originating at or near top of Stratum 2, Archaic zone at site (Funk et al., 1965; Funk, 1966a). Coll. 1965 by R. E. Funk and T. P. Weinman; subm. 1966 by R. E. Funk. New York State Mus. and Sci. Serv., New York. Comment (R.E.F.): date is much later than expected. Sample was believed assoc. with late Archaic manifestations which occurred at top of Stratum 2. However, it appears that Feature 16 actually originated at contact plane of Strata la and 2, so that sample dates small Early Woodland component at site.

\section{I-2401. Pickle Hill site, Warren County, New York 1760 в.c.

Charcoal from Pickle Hill site (43 $24^{\prime \prime} \mathrm{N}$ Lat, $73^{\circ} 33^{\prime} \mathrm{W}$ Long), Queensbury Township, Warren County, New York. Combined charcoal samples from 2 large oval cooking features which extended into subsoil below plow zone on this single-component site of late Archaic River phase (Ritchie, 1965). Coll. 1966 by Thomas and Paul Weinman; subm. 1966 by R. E. Funk. Comment (R.E.F.): date is congruent with previous estimates for River phase.

\section{Canada}

\section{Deep River series, Ontario}

Wood charcoal from refuse pit, near Deep R. $\left(46^{\circ} 06^{\prime} \mathrm{N}\right.$ Lat, $77^{\circ}$ 27' W Long), Ontario, Canada. Coll. 1962 by B. M. Mitchell; subm. 1966 by W. N. Irving, Natl. Mus. of Canada.

\section{I-2083. Deep River, No. 1}

$1820 \pm 100$

From 12 to 16 in. depth in 40 in. deep refuse pit, Site CaGi-1, Sq. D-19W. Assoc. with Vinette-1 potsherds, firestone, flint chips, ash, and wood-carbon. 
I-2084. Deep River, No. 2

80 B.C.

From 24 in. depth in 40 in. deep refuse pit, Site CaGi-1, Sq. D-19W. General Comment (B.M.M.): dates agree well with age estimate and supports chronological priority of Early Point Peninsula, Vinette-1 ware in Canada (Mitchell, 1966).

\section{Southern Indian Lake series, Canada}

Samples from $16 \mathrm{mi} \mathrm{NE}$ of South Indian Lake $\left(56^{\circ} 57^{\prime} \mathrm{N}\right.$ Lat, $98^{\circ}$ 44' W Long), Manitoba, Canada. Coll. 1965 by J. V. Wright; subm. 1966 by W. N. Irving.

\section{I-2078. HfLq-1, Samples I and II}

$435 \pm 110$

Charcoal from Trench 2, Stratum I. Comment (W.N.I.): date substantiates late position of Stratum I at HfLq-1 site and indirectly supports premise that Selkirk pottery was still in use during historic period in area as suggested by surface assoc. of pottery and European trade items at other nearby sites. Apparent survival of Selkirk pottery into historic period suggests some bands of Chipewyan and Cree shared common tradition.

I-2080. HfLq-1, Sample III

Charcoal from Trench 2, Stratum II.

\section{I-2081. HfLq-1, Sample IV}

$$
730 \pm 150
$$

Charcoal from Trench 1, Stratum II, NE quadrant. Comment (W.N.I.): agreement between Samples III and IV indicates early 12th century occupation period for Stratum II at HfLq-1 site. Selkirk ceramics were used in region a long time and not introduced at a late date.

\section{I-2082. HfLq-1, Sample V}

Charcoal from Trench 1, thin lens diverging from bottom of Stratum II. Comment (W.N.I.): agreement of date with Samples III and IV suggests thin lens below Stratum II is not significantly older than Stratum II.

\section{I-2086. Keewatin District, N.W.T.}

$$
1630 \pm 135
$$

Wood charcoal from exposed hearth, Site JjLk-4, S shore of passage between Oftedal and North Henik Lakes, Keewatin District $\left(61^{\circ} 37^{\prime} \mathrm{N}\right.$ Lat, $97^{\circ} 45^{\prime} \mathrm{W}$ Long), N.W.T., Canada. Coll. 1964 and subm. 1966 by W.N. Irving. Comment (W.N.I.): along with I-2087 and I-2089 (this date list) is 1st archaeological date from Barren Grounds. Assoc. artifacts represent form of Archaic culture (Irving, mss. in preparation). 
Lamb Pegeelak series, N.W.T.

Charred wood and charcoal from Lamb Pegeelak site, Oftedal Lake, 150 yds $S$ of outlet $\left(61^{\circ} 37^{\prime} 55^{\prime \prime} \mathrm{N}\right.$ Lat, $97^{\circ} 53^{\prime} 50^{\prime \prime} \mathrm{W}$ Long), Keewatin District, N.W.T. Coll. 1964 by G. F. Merbs (I-2089) and W. N. Irving; subm. 1966 by W. N. Irving.

\section{I-2087. Lamb Pegeelak site, No. 1}

$1110 \pm 90$

Charred $\log$ of 6 in. depth in layer of humus and charcoal, between 2 A2 (podzol) soil horizons. Comment (W.N.I.): sample dates forest fire. It is nearly contemporary with other dates on forest fires from Ennadai Lake and the Kazan R. (Bryson et al., 1965; Irving, mss. in preparation).

\section{I-2089. Lamb Pegeelak site, No. 2}

Charcoal (mostly wood) from uppermost Zone A, assoc. with flint chips and burned bone. Comment (W.N.I.): sample dates Zone A, believed younger than Zone B (Bryson et al., 1965).

\section{National Museum of Canada series, N.W.T.}

Samples from various sites in N.W.T., Canada. Coll. and subm. 1963 to 1965 by W. E. Taylor, Jr., Natl. Mus. of Canada, Ottawa.

\section{I-2052. Jackson site, No. 1}

$600 \pm 105$

Willow twigs from cultural debris on floor of house, Jackson site, Police Point, near Cape Parry $\left(70^{\circ} 12^{\prime}\right.$ N Lat, $124^{\circ} 34^{\prime}$ W Long), N.W.T., Canada. Debris, 3 to 6 in. thick, was exposed by bulldozer.

\section{I-2088. Jackson site, No. 2}

Wood fragments with adhering organic matter from cultural debris on floor of house, Jackson site, Police Point, near Cape Parry $\left(70^{\circ} 12^{\prime} \mathrm{N}\right.$ Lat, $124^{\circ} 34^{\prime}$ W Long), N.W.T., Canada. Comment (W.E.T.): artifacts from Jackson site represent developed stage of Thule culture (Taylor, $1964 ; 1965)$.

\section{I-2053. Buchanan site, No. 1}

Charcoal (granular) mixed with soil from midden 8 to 12 in. depth, Trench 2, Sq. 4, SE 1/4, Buchanan site, S bank of Ekalluk R., SE Victoria Island $\left(69^{\circ} 24^{\prime} \mathrm{N}\right.$ Lat, $106^{\circ} 15^{\prime} \mathrm{W}$ Long), N.W.T., Canada. Comment (W.E.T.): date indicates late Pre-Dorset occupation at Buchanan site (Taylor, 1967). 
I-2054. Buchanan site, No. 2

Charcoal (granular) mixed with soil from hearth remnant 4 to 5 in. depth, Trench 5, Sq. B, Buchanan site, S bank of Ekalluk R., SE Victoria Island $\left(69^{\circ} 24^{\prime} \mathrm{N}\right.$ Lat, $106^{\circ} 15^{\prime} \mathrm{W}$ Long), N.W.T., Canada.

\section{I-2055. Ballantine site}

$$
1260 \pm 95
$$

Peat from midden matrix, 5 to 8 in. depth, Trench 1, Sq. 8, Ballantine site, SW extremity of Ferguson Lake, SE Victoria Island $\left(69^{\circ} 24^{\prime} \mathrm{N}\right.$ Lat, $106^{\circ} 14^{\prime} \mathrm{W}$ Long), N.W.T., Canada. Comment (W.E.T.): date seems too young, artifacts reflect early Dorset occupation (Taylor, 1964; 1967).

\section{I-2056. Ferguson Lake site}

$\mathbf{1 0 5 5} \pm \mathbf{1 0 0}$

Peat from midden matrix, 6 to 7 in. depth, Trench 4, Sq. 4, Ferguson Lake site, SW extremity of Ferguson Lake, SE Victoria Island $\left(69^{\circ}\right.$ $24^{\prime}$ N Lat, $106^{\circ} 13^{\prime}$ W Long), N.W.T., Canada.

\section{I-2057. Wellington Bay site}

$3180 \pm 120$

Charcoal (powdered) mixed with soil, 7 to 8 in. depth, from Wellington Bay site, ca. $1 \mathrm{mi}$ SE of mouth of Ekalluk R., SE Victoria Island $\left(69^{\circ} 23^{\prime}\right.$ N Lat, $106^{\circ} 17^{\prime}$ W Long), N.W.T., Canada. From Sec. 3 of Test Cut 1, in $\mathrm{N}$ side of site which caps small hill. Comment (W.E.T.): date indicates site is of Pre-Dorset culture.

\section{I-2058. Menez site}

$$
2880 \pm 105
$$

930 B.c.

Charcoal (powdered) mixed with soil, 4 to 7 in. depth in $W$ part of Test Cut 4, from Menez site, S side of Ekalluk R., SE Victoria Island (69 $24^{\prime} \mathrm{N}$ Lat, $106^{\circ} 15^{\prime} \mathrm{W}$ Long), N.W.T., Canada. Comment (W.E.T.): date indicates Menez was occupied very late in Pre-Dorset period (Taylor, 1967).

\section{I-2059. Pembroke site}

A.D. 1245

$705 \pm 120$

Charred bone in House 5, 10 to 12 in. depth, by small hearth, Pembroke site, SE bank of Freshwater Creek, ca. 1 mi upstream from Cambridge Bay, SE Victoria Island $\left(69^{\circ} 7^{\prime} \mathrm{N}\right.$ Lat, $105^{\circ} \mathrm{W}$ Long), N.W.T., Canada. Comment (W.E.T.): date and artifacts suggest rather early Thule occupation.

\section{Europe}

\section{I-2328. Stonehenge I, England}

$4130 \pm 105$

Antler of Red Deer (Cervus elaphus) from $6 \mathrm{ft}$ depth in bottom of ditch at Stonehenge $8 \mathrm{mi} \mathrm{N}$ of Salisbury $\left(51^{\circ} 10^{\prime} 42^{\prime \prime} \mathrm{N}\right.$ Lat, $1^{\circ} 49^{\prime} 29^{\prime \prime} \mathrm{W}$ 
Long), Wiltshire, England. Coll. 1964 and subm. 1966 by R. J. C. Atkinson, Univ. College, Cardiff, Great Britain. Comment (R.J.C.A.): sample dates construction of bank and ditch, and by inference Aubrey Holes which are concentric with them (Atkinson, 1956).

\section{I-2290. Kobeaga Cave, Spain}

$$
2690 \pm 100
$$

740 B.c.

Human bone from Kobeaga Cave near village of Ispaster $\left(43^{\circ} 21^{\prime}\right.$ 14" N Lat, $1^{\circ} 07^{\prime} 11^{\prime \prime}$ E Long), Vizcaya Province, Spain. Coll. and subm. 1966 by E. Nolte y Aramburu, Las Arenas, Vizcaya, Spain. Comment (E.N.yA.): date indicates delay in Bronze age. Small mountain range in area may have been barrier against foreign cultures.

\section{E. Africa}

\section{Igbo-Ukwu series, Nigeria}

Charred bone in House 5, 10 to 12 in. depth, by small hearth, PemLat, $7^{\circ} 1^{\prime}$ E Long), E. Nigeria. Coll. 1960 (I-2008) and 1964 and subm. 1966 by Thurstan Shaw, Inst. of African Studies, Univ. of Ibadan, Nigeria, Africa.

\section{I-1783. Igho Jonah, Cutting II C}

$13,500 \pm 250$

Charcoal from depth 1.3 to $1.75 \mathrm{~m}$ in sandy deposit (Shaw, 1965b). Comment (T.S.): layer of charcoal was probably result of bush-burning, either by human activity or natural bush-fires.

\section{I-1784. Igho Jonah, Pit IV}

$1110 \pm 145$

Charcoal from composite, 1.6 to $2.9 \mathrm{~m}$ depth, in pit which contained copper, bronze, and iron work (Shaw, 1965b). Comment (T.S.): 1 of 1st dates obtained for any archaeological site at Igbo-Ukwu; earlier than anticipated.

\section{I-2008. Igbo Richard}

$1110 \pm 120$

Wood surrounding copper bosses, believed part of stool, from depth $3.3 \mathrm{~m}$ in burial chamber (Shaw, 1965b). Comment (T.S.): 1 of 1 st dates obtained for any archaeological site at Igbo-Ukwu; earlier than anticipated.

\section{Iwo Eleru series, Nigeria}

Wood charcoal ca. $15 \mathrm{mi} \mathrm{N}$ of Akure ( $7^{\circ} 24^{\prime} \mathrm{N}$ Lat, $5^{\circ} 10^{\prime} \mathrm{E}$ Long), W Nigeria. Coll. and subm. 1965 by T. Shaw.

\section{I-1753. UI $/ 651$}

$11,200 \pm 200$

9250 в.c.

From 0.70 to $1.00 \mathrm{~m}$ depth, cutting XXIII D. Associated with skeletal material. Comment (T.S.): date earlier than anticipated, but not inconsistent with assoc. type of stone industry (Shaw, 1965a). 


\section{I-1754. UI/652}

$9150 \pm 150$

7200 B.c.

From 1.00 to $1.15 \mathrm{~m}$ depth, cutting XVIII D, Level 7. Comment (T.S.): this date from different part of occupation layer, believed to have had long existence, has some confirmation for antiquity of I-1753 (Shaw, 1965a).

\section{I-1844. Grahamstown, South Africa}

$18,740 \pm 320$

Charcoal from rock shelter, Square C3, Layer 4 (cultural horizon), at depth ca. $1 \mathrm{ft} 3$ in., Howieson's Poort (32 $22^{\prime} \mathrm{S}$ Lat, 26 $6^{\circ} 8^{\prime} \mathrm{E}$ Long), near Grahamstown, Cape Province, South Africa. Coll. and subm. 1965 by J. Deacon and H. J. Deacon, Albany Mus., Grahamstown, South Africa. Comment (H.J.D.): date, slightly older than expected, indicates crescents and backed blades characteristic of Wilton Later Stone Age culture were being made as early as 18,000 yr ago in this region of South Africa (Stapleton and Hewitt, 1927; 1928).

$$
\text { F. Iran }
$$

\section{Deh Luran series, Iran}

Samples from 2 sites, Ali Kosh and Tepe Sabz, in Deh Luran region $\left(32^{\circ} 15^{\prime}\right.$ to $32^{\circ} 30^{\prime} \mathrm{N}$ Lat, $47^{\circ} 8^{\prime}$ to $47^{\circ} 24^{\prime} \mathrm{E}$ Long), SW Iran. Coll. 1963 by Frank Hole and James Neely; subm. 1964 by Frank Hole, Rice Univ., Houston, Texas.

\section{I-1489. AK $-94-691$}

$7670 \pm 170$ 5720 в.c.

Carbonized seeds and ash from Ali Kosh (Bus Mordeh phase), Square 94, $690 \mathrm{~cm}$ depth. Directly above sterile sand. Comment (F.H.): estimated age between 7000 to 8000 B.c.

I-1491. AK $-69-260$

$8100 \pm 170$

Charcoal and ash from Ali Kosh (Ali Kosh phase), Square 69, 260 cm depth.

I-1493. TS $-25-501$

$6470 \pm 160$

Charcoal from Tepe Sabz (Mehmeh phase), Square 25, $500 \mathrm{~cm}$ depth.

\section{I-1494. AK $\quad$ - $59-150$}

$7820 \pm 190$

$\mathbf{5 8 7 0}$ в.c.

Charcoal and ash from Ali Kosh (Mohammad Jaffar phase), Square $59,150 \mathrm{~cm}$ depth.

\section{I-1496. AK - $91-525$}

$7380 \pm 130$

5430 B.c.

Charred seeds and ash from Ali Kosh (Bus Mordeh phase), Square 91, $525 \mathrm{~cm}$ depth. Comment (F.H.): estimated age 7000 to 8000 в.c. 
I-1497. TS $-20-968$

$6740 \pm 190$

4790 в.c.

Carbonized wood from Tepe Sabz (Sabz phase), Square 20, 960 to $980 \mathrm{~cm}$ depth. Comment (F.H.): estimated age 5000 to 6000 B.c.

I-1500. TS $-7-380$ and TS $-9-400$

$\mathbf{5 4 1 0} \pm 160$

Carbonized wood from Tepe Sabz (Mehmeh phase), 2 samples combined, Square 7, $380 \mathrm{~cm}$ depth and Square $9,400 \mathrm{~cm}$ depth. Comment (F.H.): estimated age 4000 в.c.

\section{I-1501. TS $-21-680$}

$7460 \pm 160$

Charcoal from Tepe Sabz (Khazineh phase), Square 21, $680 \mathrm{~cm}$ depth.

I-1502. TS - $15-312$

$6060 \pm 140$

Charred wood, seeds, and dung from Tepe Sabz (Bayat phase), Square $15,310 \mathrm{~cm}$ depth.

General Comment (F.H.): this series of dates are 1st obtained from SW Iran for prehistoric period. Although dates show some marked departures from the expected, we have a fairly good idea, from stratigraphic succession and from dates obtained at other sites, what chronological limits of Deh Luran sequence are. We cannot estimate as well, duration of any phase within sequence (Hole, 1962; Hole and Flannery, 1962; Hole et al., 1965; UCLA IV).

\section{G. Peru}

\section{Chilca Canyon series, Peru}

Samples from Cave I in upper Chilca Canyon, central coast of Peru. Coll. 1967 by Bernardino Ojeda and Frederic Engel subm. 1967 by Frederic Engel, Inst. of Anthropol., Natl. Agrarian Univ., Lima, Peru.

\section{I-3160. Cave I, V-2623, Peru}

$9940 \pm 200$

Ashes, peat, and carbonized plants mixed with fine gravel from deepest level in Cave I, Site 12B-VI-470, Level 900, elev. 3,600 m, upper Chilca Canyon $\left(12^{\circ} 14^{\prime}\right.$ to $15^{\prime} \mathrm{S}$ Lat, $76^{\circ} 21^{\prime}$ to $22^{\prime} \mathrm{W}$ Long), central coast of Peru.

\section{I-3161. Cave I, V-2643, Peru}

$4810 \pm 125$

Charcoal and mat material from Level 2 in cave "Tres Ventanas," elev. 3,900 m, upper Chilca Canyon (12 $12^{\circ} 14^{\prime \prime} \mathrm{S}$ Lat, $76^{\circ} 22^{\prime} 23^{\prime \prime} \mathrm{W}$ Long), central coast of Peru. Assoc. with unknown type of pottery. 


\section{I-3162. Casma Valley, Peru}

Charcoal from inside house on terrace of Bombon Grande, Site 8 C-X-4, Level 1, elev. $650 \mathrm{~m}$, Casma valley (9॰ $31^{\prime} 32^{\prime \prime} \mathrm{S}$ Lat, $77^{\circ} 56^{\prime} 57^{\prime \prime}$ W Long), N coast Peru. Coll. 1966 by Frederic Engel and Bernardino Ojeda; subm. 1967 by Frederic Engel. Comment (F.E.): sample helps date early canal irrigated complex with temple, dwellings, and planting terraces belonging to unidentified culture.

\section{REFERENCES}

Date lists:

Isotopes $\mathbf{V}$

Trautman and Willis, 1966

UCLA IV

Berger, Fergusson, and Libby, 1965

Aartolahti, Toive, 1966, Immigration and propagation of the spruce tree in Finland: Ann. Bot. "Fennici", v. 3, no. 2, p. 368-369.

Andrews, J. T., 1966a, Pattern of coastal uplift and deglacierization, west Baffin Island, N.W.T.: Geog. Bull., v. 8, no. 2, p. 174-193.

1966b, Radiocarbon dates of the Geographical Branch - 1955-1966, Part I: Geog. Bull., v. 8, no. 4.

Atkinson, R. J. C., 1956, Stonehenge: London, Hamish Hamilton.

Baumhoff, M. A. and Byrne, J. S., 1959, Desert Side-Notched points as a time marker in California: Repts. of the Univ. of California, Berkeley, Archaeol. Survey, no. 48 , p. $32-65$.

Berger, R., Fergusson, G. J., and Libby, W. F., 1965, UCLA Radiocarbon Dates IV: Radiocarbon, v. 7, p. 336-371.

Black, R. F., 1964, Gubik Formation of Quaternary age in northern Alaska: U.S. Geol. Survey Prof. Paper 302-C, p. 59-91.

Boulton, G. S. and Worsley, P., 1965, Late Weichselian glaciation in the CheshireShropshire basin: Nature, v. 207, no. 4998, p. 704-706.

Brown, J., 1965, Radiocarbon dating, Barrow, Alaska: Arctic, v. 18, p. 36-48.

Brown, Jerry and Sellmann, P. V., 1966, Radiocarbon dating of coastal peat, Barrow, Alaska: Science, v. 153, p. 299-300.

Bryson, R. A., Irving, W. N., and Larsen, J. A., 1965, Radiocarbon and soil evidence of former forest in the southern Canadian tundra: Science, v. 147, p. 46-48.

Budinger, T. F. and Enbysk, B. J., 1960, Cobb Seamount, a deep-sea feature off the Washington coast: Univ. of Washington, Dept. of Oceanog. Tech. Rept. no. 60, p. 1-83.

Bullen, R. P. and Bryant, W. J., 1965, Three archaic sites in the Ocala National Forest, Florida: The W. L. Bryant Am. Studies, rept. no. 6, p. 21-28.

Coleman, A. P., 1936, Geology of the north shore of Lake Ontario: Ontario Dept. Mines, 45th Ann. Rept., v. 7, p. 37-74.

Collier, Donald, Hudson, A. E., and Ford, Arlo, 1942, Archaeology of the upper Columbia region: Univ. of Washington, Pubs. in Anthropol., v. 9, no. 1.

Davis, W. A., 1966, Report on current research: Am. Antiquity, v. 31, no. 4.

DeLaguna, Frederica, 1934, The archaeology of Cook Inlet, Alaska: Philadelphia, Univ. of Pa. Press.

Frey, D. G., 1951, Pollen succession in the sediments of Singletary Lake, North Carolina: Ecology, v. 32, no. 3, p. 518-533.

Funk, R. E., Weinman, P. L., and Weinman, T. P., 1965, A stratified site at Lake George: Pennsylvania Archaeologist, v. 35, no. 1 .

Funk, R. E., 1966a, An archaic framework for the Hudson Valley: Ph. D. dissertation, Columbia Univ.

Gifford, E. W. and Schenk, W. E., 1926, Archaeology of the southern San Joaquin valley: Univ. of California Pubs. in Am. Archacol. and Ethnol., v. 23, p. 1-122.

Gravenor, C. P., 1957, Surficial geology of the Lindsay-Peterborough area, Ontario, Victoria, Peterborough, Durham, and Northumberland counties, Ontario,. Geol. Survey Canada Mem. 288, 60 p.

Harrington, M. R., 1957, A Pinto site at Little Lake, California: Southwest Mus. (Los Angeles) Papers, no. 17. 
Harrison, D. A., 1964, A reconnaissance glacier and geomorphological survey of Duart Lake area, Bruce Mountains, Baffin Island, N.W.T.: Canada Dept. Mines and Tech. Surveys Geog. Br. Geog. Bull. 22, p. 57-71.

Hole, Frank, 1962, Archeological survey and excavation in Iran, 1961: Science, v. 137, p. $524-526$.

Hole, Frank and Flannery, K. V., 1962, Excavations at Ali Kosh, Iran, 1961: Iranica Antiqua, v. 2, p. 97-148.

Hole, Frank, Flannery, K. V., and Neely, J. A., 1965, Early agriculture and animal husbandry in Deh Luran, Iran: Current Anthropol., v. 6, p. 105-106.

Howard, J. H. and Gant, R. D., 1966, Archaeological salvage investigations in the Gavins Point reservoir area, Lewis and Clark Lake, Nebraska and South Dakota, 1963 and 1964: Univ. of So. Dakota Mus., Archaeol. Studies circ. no. 11.

John, B. S., 1965, A possible Main Würm Glaciation in West Pembrokeshire: Nature, v. 207 , no. 4997 , p. $622-623$. Johnson, D. W., 1925, The New England-Acadian shoreline: New York, John Wiley
\& Sons, p. 535-537.

Kempton, J. P., 1963, Subsurface stratigraphy of Pleistocene deposits of central northern Illinois: Illinois Geol. Survey Circ. 356, p. 43.

Leighton, M. M. and Willman, H. B., 1950, Loess formations of the Mississippi valley: Jour. Geology, v. 58 , no. 6, p. 599-623. Løken, O. H., 1966, Baffin Island refugia older than 54,000 years: Science, v. 153, p.
1378-1380.

McBryde, Isabel, 1961, New radiocarbon dates for Australia: Antiquity, v. 35, p. 312-313. McCarthy, F. D., 1961, Report on Australia and Melanesia: Asian Perspectives, v. 5,
p. 141-155.

McIntire, W. B. and Morgan, J. P., 1963, Recent geomorphic history of Plum Island, Mass., and adjacent coasts: Louisiana State Univ. Studies, Coastal Studies Ser. no. $8,44 \mathrm{p}$.

Mitchell, B. M., 1966, Preliminary report on a woodland site near Deep River, Ontario: Natl. Mus. of Canada, Anthropol. Paper no. XI.

Mölder, Valovirta and Virkkala, Uber Spätglazialzeit und frühe Postglazialzeit in Südfinnland: Bull. Comm. géol. Finlande 178.

Mulvaney, D. J., 1962, Advancing frontiers in Australian archaeology: Oceania, v. 33, p. $135-138$.

Osborne, Douglas, Crabtree, Robert, and Bryan, Alan, 1952, Archaeological investigations in the Chief Joseph reservoir: Am. Antiquity, v. 17, no. 4, p. 360-373.

Redfield, A. C. and Rubin, Meyer, 1962, The age of salt marsh peat and its relation to recent changes in sea level at Barnstable, Mass., Proc. Natl. Acad. Sci., v. 48, no. p. $1728-1735$.

Reed, E. C. and Dreeszen, V. H., 1965, Revision of the classification of the Pleistocene deposits of Nebraska: Nebraska Geol. Survey Bull., no. 23, fig. 10, p. 36 and columnar sec. 18 , p. 62 , p. 42 .

Ritchie, W. A., 1965, The archaeology of New York State: Garden City, N.Y. Natural History Press, p. 124-131, 271-310.

Royse, C. F., Jr., 1964, Sediments of Willapa submarine canyon: Univ. of Washington, Dept. of Oceanog. Tech. Rept. no. 111.

Ruhe, R. V., Rubin, Meyer, and Scholtes, W. H., 1957, Late Pleistocene radiocarbon chronology in Iowa: Am. Jour. Sci., v. 255, no. 10, p. 617-689.

Sellmann, P. V., Brown, J., and Schmidt, R. A. M., 1965, Late-Pleistocene stratigraphy Barrow, Alaska: Paper presented at 7th International Congress of INQUA, Boulder, Colorado.

Sellmann, P. V., 1967, Geology of U.S. Army CRREL permafrost tunnel section, Fairbanks (Fox), Alaska: U.S.A. CRREL Tech. Rept. no. 199.

Shaw, Thurstan, 1965a, Excavations at Iwo Sleru 1965: West African Archaeolog. Newsletter, no. 3, p. 15-17. 1965b, Further excavations at Igbo-Ukwu, Eastern Nigeria: an interim
report: Man, v. LXV, no. 217, p. 181-184.

Stapleton, P. and Hewitt, J., 1927, Stone implements from a rock-shelter at Howieson's Poort near Grahamstown: South African Jour. Sci., v. XXIV, p. 574-587. 1928, Stone implements from Howieson's Poort near Grahamstown: South
African Jour. Sci., v. XXV, p. 399-409.

Strong, W. D., 1935, An introduction to Nebraska archeology: Smithsonian Misc. Colln., v. 93, no. 10, p. 296, pl. 24 and 25. 
Swanson, E. H., Jr., 1959, Archaeological survey of the Methow valley, Washington: Tebiwa, v. 2., no. 1, p. 72-76.

Synge, F. M., 1964, The age of Irish Sea Till at West Pembrokeshire: Geol. Assoc. Proc., v. 75 , p. 431.

Taylor, W. E., Jr., 1964, Interim account of an archaeological survey in the Central Arctic, 1963: Anthropol. Papers of the Univ. of Alaska, v. 12, no. 1.

1965, An archaeological survey between Cape Parry and Cambridge Bay, N.W.T., Canada, 1963: ms. Natl. Mus. of Canada files, Ottawa.

1967, Summary of archaeological field work on Banks and Victoria Islands, Arctic Canada, 1965: Arctic Anthropol., v. IV, no. 1, p. 221-243.

Trautman, M. A., and Willis, E. H., 1966, Isotopes, Inc. radiocarbon measurements V: Radiocarbon, v. 8, p. 161-203.

Vasari, Yrjö, 1965a, Studies on the vegetational history of the Kuusamo district during the Late-Quaternary period III: Ann. Bot. "Fennici", v. 2, no. 3, p. 219-235.

$1965 \mathrm{~b}$, Studies on the vegetational history of the Kuusamo district during the Late-Quaternary period IV: Ann. Bot. "Fennici", v. 2, no. 3, 249-274.

Wedel, W. R., 1941, Archaeological investigations at Buena Vista lake, Kern County, California: Bur of Am. Ethnol., Bull. 130

Whitehead, D. R., 1963, "Northern" elements in the Pleistocene flora of the Southeast: Ecology, v. 44, p. 403-406.

1964, Fossil pine pollen and full-glacial vegetation in southeastern North Carolina: Ecology, v. 45, no. 4, p. 767-777.

Workman, William, 1965, Prehistory at Port Moller, Alaska: Arctic Anthropol., v. 3, no. 2 . 